\title{
REALIDADES Y FICCIONES DE LA RUSIA POSTCOMUNISTA EN EL CONCIERTO (2009), DE RADU MIHAILEANU
}

\author{
Realities and Fictions of Post-Communist Russia in \\ Le Concert (2009), by Radu Mihaileanu
}

Igor Barrenetxea Marañón

ibm@euskalnet.net

Universidad Internacional de La Rioja (UNIR). España

Fecha de recepción: 13/12/2018

Fecha de aceptación: 17/05/2019

Resumen: Este artículo analiza las claves del filme El Concierto (2009), desde la perspectiva de las relaciones de historia y cine, impulsadas por Marc Ferro, Robert Rosenstone y José María Caparrós Lera, entre otros. En otras palabras, el tratamiento del cine como un documento histórico más, con su propio lenguaje, y que se configura, además, como un agente de la Historia. El Concierto nos muestra, desde un retrato humorístico, las realidades y ficciones de la Rusia postcomunista, sus nuevas idiosincrasias, su deuda con el pasado y los muchos conflictos sociales y emocionales dejados sin resolver tras su cierre. El filme no pretende ser una exacta radiografía de la sociedad rusa, sino una metáfora muy elocuente del duro retrato social (miseria, heridas y mafias) y herencia dejada tras el totalitarismo soviético.

Palabras clave: Rusia; Postcomunismo; Historia; Memoria; Cine; Mihaileanu.

Abstract: This article analyses the keys in the movie Le Concert (2009), from the point of view of the relationship between History and cinema, inspired by Marc Ferro, Robert Rosenstone and José María Caparrós Lera, among others. In other words, the treatment of movies as yet another historical document, with its own language and which, also, shapes itself as a historical agent. Le Concert shows us from a humoristic portrait, the realities and fictions of pot-communist Russia, its new idiosyncrasies, its debt to the past and the many social and emotional conflicts left unsolved after its shut down. The film does not intend, by any means, to be an exact X-ray of Russian society, but a rather eloquent metaphor of the tough social portrait (misery, wounds and mafias) and inheritance left behind by the Soviet totalitarianism.

Keywords: Russia; Post-communism; History; Memory; Cinema; Mihaileanu. 
SUMARIO: 1. Introducción. 2. Rusia post-comunista. 3. Revisar los traumas. 3.1. Sinopsis del filme. 3.2. Director. 4. Entre el pasado y el presente. 4.1. La sociedad rusa actual. 4.2. Pasado, presente y future. 4.3. Música, persecución judía y la última armonía. 5. Conclusiones. 6 . Referencias bibliográficas.

Si hay un mito que es necesario desmentir es esta visión de Rusia como un país exótico y lejano

(Figes, 2006, 32).

\section{INTRODUCCIÓN}

Como seres humanos sentimos una inapelable necesidad de volver a bucear en nuestro presente-pasado. $Y$ el cine se ha convertido en un elemento fundamental para acercarnos a él desde puntos de vista singulares y fascinantes, al margen de la Historia académica. Pues no solo reproduce vivencias personales (más o menos fieles a tales hechos), sino que nos permite hacerlo desde un enfoque original y profundamente humano. En otras palabras, nos construye un imaginario social y lo percibimos de forma personal, lo cual se convierte en una interpelación directa sobre nuestro devenir (Ferro, 1995; Burke, 2001 y Rosenstone, 2014). Pero, además, lo puede hacer desde planos múltiples, ya sea desde la recreación histórica (toda la trama transcurre en los hechos pretéritos) o desde la actualidad (esa sensación de presente que es capaz de trasmitirnos el cine) hacia atrás; o, simultáneamente, combinando pasado y presente (la técnica del flash-back), en una traslación sugerente e intensa.

Así mismo, el cine nos recuerda que todas las grandes historias se componen de una suma de relatos individuales, de registros vitales, no siempre vinculados a grandes personajes sino a seres normales y corrientes, con los que como ciudadanos nos podemos sentir tremendamente identificados. $Y$ no porque la Historia no se acerque a estos aspectos, que lo hace, sino porque la capacidad evocadora y recreadora del cine nos hace sentir más cerca de los protagonistas, en esa trasferencia emocional que de manera tan singular nos proporcionan las imágenes (con la música, el gesto de los actores y la ambientación). Y ahí es donde la credibilidad de la puesta en escena acaba por hacernos creer que esta realidad ficcionada es, de alguna forma, verdad (Hueso Montón y Camarero Gómez, 2014; y Bolufer, Gomis, Hernández, 2105).

Desde esta perspectiva el director rumano, afincado en Francia, Radu Mihaileanu, reúne en El Concierto una serie de magníficos ingredientes, donde la historia (presentando la historia actual de Rusia), la memoria (traumas y recuerdos de la URSS) (Frentress y Wikham, 2003 y Halbwachs, 2004) y la sociedad (actual) se funden en un mismo abrazo, constituyendo las piezas fundamentales de una narración llena de ficción y también llena de radiografía social, secundado muy bien por actores europeos como Aleksei Gukov, Mélanie Laurent, Dimitri Nazarov e Valeri Barinov, entre otros. 
De hecho, la película tuvo buena acogida en España, así, Javier Ocaña señala de ella: «El concierto mezcla la denuncia del ocaso artístico de la antigua URSS con la desvergonzada chulería de los nuevos magnates del gas y del petróleo», y salvo algunos elementos que no cree que casen bien, concluye: "la comedia acaba triunfando sobre los pequeños desperfectos sentimentales» (Ocaña, 2010). Y el crítico José Manuel Cuellar destaca cómo el director "ha sabido captar la belleza en una sola escena (la última del concierto), tan sublime que completa y eleva de nivel una película de por sí muy estimable, aunque un tanto ingenua» (Cuéllar, 2010). En la prensa británica, Philip French destaca la originalidad de la propuesta, si bien matiza que las situaciones inverosímiles y el sentimentalismo lastran su acabado final (French, 2010). Para el crítico estadounidense Stephen Holden, de forma más dura, considera que El Concierto es una sátira imposible aderezada de muchos clichés y que peca de ser demasiado irreal en su planteamiento (Holden, 2010). En cambio, la crítica francesa sería más entusiasta en su valoración. Cyril Masurel destacará, entre otras virtudes, que Mihaileanu «dirige a sus actores y puntúa de manera brillante» (Masurel, 2009).

El filme, a pesar de todo, recibiría una avalancha de premios y nominaciones. Conseguiría dos Premios César de la Academia francesa (2009), en las categorías de mejor música y mejor sonido, además de otras cuatro nominaciones a mejor director, película, mejor guion original y montaje. Obtendría, así mismo, el Premio del Público del Cinemania Film Festival (2009), el Premio David Di Donatello (2010), de la Academia italiana, cuatro premios más en los Gopo (2010), de la Academia del cine rumano, entre los que destacan los de mejor edición, música y mejor maquillaje, y el premio a mejor director del Sindicato de actores italianos (2010). También fue nominada a los Globos de Oro (USA, 2011), como mejor película extranjera, a mejor filme en los Premios del Cine Europeo, a mejor filme de los Premios Gaudí (2011), en España, y mejor filme en el Festival de cine de Vukovar (Filmaffinity y Imdb).

\section{RUSIA POST-COMUNISTA}

El contexto donde se desarrolla el filme es la Rusia actual, momento de su rodaje, aunque hay referencias a los años 80 , al final de la etapa de Brezhnev al frente de la URSS. El fin del régimen comunista, el 31 de diciembre de 1991, tras los ímprobos intentos de Gorbachov de querer reflotarlo y darle viabilidad, derivó en un largo proceso de apertura tanto política y económica como social que estuvo lleno de inestabilidad y dificultades (Meyer, 2009, pp. 464-476 y Gessen, 2018a, pp. 132-136). No fue una transición fácil pasar de un sistema cerrado a otro de mercado libre caracterizado por un capitalismo salvaje (Service, 2000, pp. 449-469). En ese marco, escribe Service, la «Unión Soviética no había acabado sus 
días con una explosión, sino con un gemido. El Partido Comunista, la ideología, la bandera y el himno del estado y la revolución de octubre fueron arrojados a un agujero negro de la historia» (Service, 2000, p. 471). Aunque, al principio, se llevaría a cabo una cierta limpieza de simbología soviética y recuperación de otra zarista, más tarde, Putin se encargaría de volver a utilizar algunos de aquellos elementos genuinamente rusos para constituir un continuismo histórico sin renunciar ni al zarismo ni a la URSS, para darle firmeza a un renovado nacionalismo patrio (Service, 2005, pp. 247-249; Shevtsova, 2007 y Rangsimaporn, 2009) ${ }^{1}$. Todo ello tuvo su repercusión inmediata. Boris Yeltsin iba a conducir el nuevo destino de Rusia, iniciando unas reformas profundas mediante decretos presidenciales. Había despreciado la actitud timorata de Gorbachov, en algunos momentos, pero al mismo tiempo utilizaba los mismos rudimentos autoritarios y despóticos del fallecido régimen comunista. Sin embargo, el efecto negativo de la apertura dio lugar a que, en 1992, los precios aumentaran nada menos que el 245 por 100, lo cual hizo que afectara a las familias rusas ante el temor a un «empobrecimiento masivo» (Service, 2000, p. 472).

Así mismo hay que considerar que toda la industria, las minas y los koljoses agrícolas, en suma, los medios productivos del país pertenecían al Estado, eso implicaba que había que transformar la mayoría de ellos en empresas privadas y el proceso que se siguió, sin ser catastrófico, tampoco fue el más adecuado para el ciudadano medio.

En un primer momento, la idea fue facilitar que los ciudadanos pudieran adquirir, en un sistema de vales, las nuevas empresas que se crearan. Pero la realidad fue otra muy distinta. La situación empeoró sin remedio, las arcas del Estado no podían pagar a los koljoses por sus alimentos, el nivel productivo de la industria descendía de forma alarmante y la inflación crecía de forma desmesurada. Y muchos se dedicaban a la venta de cigarrillos en el metro y otras actividades propias del mercado negro y la economía sumergida, incluidos robos de poca monta. En las calles abundaban los vendedores ambulantes ilegales que sorteaban las detenciones policiales mediante sobornos, donde se podía encontrar todo lo que escaseaba, desde bebidas, alcohol, relojes, a Biblias y revistas pornográficas, incluidos artículos de importación, muy demandados, de los que obtenían pingües beneficios (Service, 2000, pp. 477-478). Pero, a pesar de todo, «la pobreza en sus variantes más terribles estaba muy extendida, y proliferaron asentamientos de tiendas de campaña para gente sin vivienda hasta en Moscú» (Service, 2000, p. 478). A la par que, para 2015, se convertiría en la ciudad con mayor número de multimillonarios del mundo (Matías López, 2002, pp. 157-169 y Taibo, 2017,

${ }^{1}$ Se mantuvo la bandera tricolor y el águila bicéfala de los Romanov y, al mismo tiempo, se restauró el himno de la URSS, con la letra revisada, así como la bandera roja del Ejército Rojo con su estrella dorada. 
p. 37). Una suerte de nuevos ricos cuya ostentación contrasta, claramente, con la de los ciudadanos más humildes (Matías López, 2002, p. 18). La suerte de los rusos en aquellos años no fue nada halagüeña.Se había producido un grave deterioro en la asistencia sanitaria (buque insignia del comunismo), los índices de contaminación eran muy elevados y la disminución de los ingresos de las familias muy preocupante, debido a la devaluación del rublo (y el escaso incremento de los salarios). Los más afectados, sin duda, en esta falta de perspectivas, eran los ancianos, pobres y enfermos. Por supuesto, el propio debilitamiento del Estado trajo consigo el surgimiento de una violenta delincuencia y redes mafiosas, amén de una pasmosa corrupción, todavía muy presente en todos los órdenes del sistema (Service, 2005, p. 8 y Taibo, 2017, p. 39). Pero nada era casual, configuraban parte del legado leninista, pues «la Rusia actual es hija de la URSS» (Service, 2005, p. 108).

Se asesinó a políticos y periodistas de investigación que denunciaban los excesos, mientras se atacaba a ancianos o familias para apoderarse de sus inmuebles; se eliminaba a empresarios rivales, se vendían armas a las guerrillas chechenas o se exportaba combustible nuclear a través de un ilegal mercado negro (Service, 2000, pp. 479-480 y Matías López, 2002, pp. 154-156). El leve crecimiento económico, así mismo, no ha supuesto una preocupación del Estado por invertir en infraestructuras, "así lo demuestran el lamentable estado de carreteras y ferrocarriles» (Taibo, 2017, p. 44).

En 2010, había 18 millones de personas que vivían por debajo del umbral de la pobreza y eso ha ido aumentando con los años. Pero no parecía que se diese una movilización social crítica capaz de revertir la deriva autoritaria. De ahí que, según Greene, «en 1991, la sociedad civil en Rusia murió con la Unión Soviética» (2011, p. 82).

A nivel político, el favor social con el que contó Boris Yeltsin, una vez se puso al frente de la Federación rusa, no correspondía con las ilusiones y esperanzas que Europa puso en él. Yeltsin no gobernaría como un presidente democrático, había demasiados partidos e inestabilidad. Por el contrario, el político moscovita supo muy bien desenvolverse en los resortes del poder y utilizar la baza del populismo durante sus conflictivos y tensos años de gobierno para seguir al frente del Estado (Meyer, 2009, p. 503).

Finalmente, ante su delicado estado de salud y pérdida de prestigio, daría el relevo a un joven y desconocido Vladimir Putin. Desde entonces, y salvo un breve periodo de tiempo, entre 2008 y 2012, en el que Dmitri Medvédev se convirtió en presidente (con el beneplácito de Putin), ha regido los destinos de Rusia, en lo que vino a definir como una democracia soberana más bien dirigista (Gessen, 2018b y Lee Myers, 2018). 


\section{REVISAR LOS TRAUMAS}

\subsection{Sinopsis del filme}

Andréi Simonovich Filipov fue, años atrás, uno de los más destacados directores de la famosa Orquesta del Teatro Bolshói. Caído en desgracia durante la época comunista, ahora, tras el fin de la URSS, trabaja como conserje del mismo lugar que en tiempos pasados le dio tanta fama. Se dedica a escuchar, desde bastidores, lo que antaño conformaba su vida. Sin embargo, un buen día cae en sus manos una invitación para que la Orquesta del Bolshói actúe en el Théâtre du Châtelet, en París, en sustitución de la Orquesta Filarmónica de Los Ángeles. Y, entonces, se le ocurre un plan. Tiene una deuda con el pasado que quiere, en cierta manera, satisfacer. Para ello no duda en ponerse en contacto con el responsable del Châtelet y confirmar la cita. Pone dos condiciones: que actúe la aclamada y joven violinista AnneMarie Jacquet y toque el concierto para violín de Tchaikovski. Ambas condiciones son aceptadas. Así que, a partir de ese momento, Filipov hablará con antiguos músicos amigos suyos para hacerse pasar por el Bolshói. No duda, incluso, en contar con un antiguo miembro del KGB, Iván Gavrilov, que sigue soñando con tiempos mejores y tiene deseos de regresar a París para ponerse en contacto con el Partido Comunista. Movidos por diversos motivos, todos los integrantes viajan a París.

\subsection{Director}

Radu Mihaileanu nació en Rumanía, en 1958, en el seno de una familia judía. En sus inicios formó parte como autor, director de escena y actor en la compañía teatral del Teatro Yiddish de Bucarest. Pero en 1980 abandonó el país y se trasladó a Israel. Más tarde, iría a Francia donde cursaría estudios en el Instituto de Estudios Superiores de Cinematografía (IDHEC). Comenzaría su carrera como ayudante de dirección bajo las órdenes de directores como Marco Ferreri, Fernando Trueba, Nicole Garcia y Edouard Niermans. En su haber como cineasta cuenta con Traidor (1993), El tren de la vida (1998), que le daría el espaldarazo internacional, logrando varios premios importantes ${ }^{3}$. Después seguirían sus siguientes largometrajes, Vete

2 2009. País: Bélgica, Francia, Italia, Rumanía. Dirección: Radu Mihaileanu. Argumento: Héctor Cabello Reyes (historia original), Thierry Degrandi. Guión: Radu Mihaileanu, Matthew Robbins y Alain-Michel Blanc. Música: Armand Amar.Fotografía: Laurent Dailland. Intérpretes: Aleksei Guskov, Mélanie Laurent, Dmitri Nazarov, Valeriy Barinov, François Berléand, Miou-Miou y Lionel Abelanski. Duración: 119 min.

${ }^{3}$ Fue nominada en los Oscars en las categorías de mejor guión y mejor actor, premio Fipresci en Venecia, premio del público en Sundance, David di Donatello a la mejor película extranjera en Roma. 
y vive (2005), El Concierto (2009), La fuente de las mujeres (2011) y La historia del amor (2016).

El argumento del filme, cuenta Mihaileanu en una entrevista ${ }^{4}$, se lo propuso un productor. La idea partía de como una falsa orquesta se hacía pasar por el auténtico Bolshói y daba un concierto en París. El tema de la impostura (tratado ya con antelación en su segundo filme, El tren de la vida) le debió resulta relevante porque su propio padre tuvo que cambiarse el apellido (de Buchmann a Mihaileanu) durante la guerra para poder sobrevivir. A partir de ahí, él mismo desarrollaría un nuevo guion que daría forma a la historia definitiva. La película sería rodada mayormente en Rumanía.

Cuenta el director que necesitaron rodar algunas tomas en Moscú. Pero a pesar de haber solicitado el correspondiente permiso hacía seis meses, no habían obtenido respuesta. Al final, gracias a la intervención del protagonista, Alexei Guskov, lo obtuvieron. Además, iba a contar con la colaboración de Armad Amar quien iba a componer la partitura original de la película, utilizando para ello una pista compuesta por el propio director (Le Trou Normand) y una selección de piezas clásicas de Mahler, Mendelssohn, Mozart y Khachaturian, además, claro está, del mítico concierto para violín de Tchaikovski, pieza clave de la trama (Cineuropa y Lahiguera).

\section{ENTRE EL PASADO Y EL PRESENTE}

\subsection{La sociedad rusa actual}

Con el fin de la URSS, la sociedad rusa se tuvo que adaptar a los nuevos tiempos, a nuevos trabajos precarios y mal pagados a aceptar pasadas realidades. Ya nada es lo que era antes. El capitalismo entraba con fuerza en una sociedad que no estaba preparada para asumirlo con tanta crudeza, a pesar de las promesas de Yelsin de instaurar los tres pilares básicos: democracia, economía de mercado y derechos humanos (Service, 2005, p. 28). Rusia, sintetiza Meyer, vivió en una década «una metamorfosis espectacular, incompleta, frustrante para los que la sufren sin recibir los beneficios que otros gozan» (Meyer, 2009, p. 506). Se creía que «el mercado, más que las agencias del Estado, iba a ser la fuerza motora de la transformación» (Service, 2005, p. 29). Pero el tiempo mostró que no sería así y que, sin una regulación adecuada, el perfil de la sociedad estaría muy alejado de los parámetros de la Europa Occidental. Muy pronto abundaron los nuevos ricos que hacían ostentación de su opulencia, mafiosos vinculados a la clase política ${ }^{5}$, pobreza y, en general, se

${ }^{4}$ <https://www.vertigofilms.es/pressbooks/elconcierto.pdf> [Consultado el 28/04/2018].

${ }^{5}$ Service considera muy inadecuado tildar a las bandas criminales como mafia, porque considera que no se asemejan a la forma de actuar y organizarse de la mafia siciliana, por 
vislumbraría una degradación social que afectaría a la gente corriente, en la que algunos reivindicarían idealizadoramente las viejas glorias soviéticas.

El inicio del filme es muy ilustrativo de muchos aspectos de esta nueva sociedad. El protagonista, Andréi, sigue aferrado y añorando sus viejos tiempos como gran maestro de orquesta que fue. Mientras el nuevo Bolshói ensaya, él gesticula desde el graderío, como si fuese todavía el director. Cuando la música va a llegar al clímax, de pronto, le suena el móvil y chafa el ensayo. Tiene que huir corriendo. Es su mujer. Le pide varios figurantes más porque algunos con los que contaba se han ido a un funeral del jefe de un supermercado, debido a que allí les pagan más. Rápidamente, este estilo tan desenfadado nos muestra que la película va a discurrir en un tono de comedia.

Al poco se muestra otro momento llamativo. La interrupción no ha gustado a Leonid Dimitrievich, el actual director del teatro, quien, acercándose al salón donde se encuentra Andréi, le repite que tiene terminantemente prohibido acudir a los ensayos. Andréi, apocado por los malos modos y la actitud agresiva del otro, le recuerda su promesa de que algún día podrá volver a dirigir. Pero este le responde que ya llegará el momento, sin comprometerse a nada. Para humillarle un poco más le lleva a su despacho y le reprende que no esté lo suficientemente limpio de polvo: «¿Así es como demuestra su amor por el Bolshói? ¿Cómo podría confiar en usted? Hablaremos de dirigir la orquesta cuanto todo esté limpio». Y Andréi, antiguo director de la orquesta del Bolshói, en un acto de orgullo, levanta la mirada y le responde: «Estará limpio». Aunque el otro le ordena imperativo: «Antes de mañana por la mañana». Así que no le queda más opción que cumplir la orden. Está claro que el pobre Andréi ha de mostrarse sumiso y complaciente. Pero mientras se afana por limpiar el despacho suena el fax avisando que llega un mensaje. Y cuando lo lee se le iluminan los ojos. Accede al ordenador y borra el mensaje que le ha llegado a su correo para que no quede constancia.

Una vez de regreso a su domicilio, conoceremos a la mujer de Andréi, Irina, que se dedica a contratar figurantes para diferentes eventos públicos, políticos y sociales. Anda detrás de que la contraten para organizar la fiesta de la boda de un empresario conocido, Genkin. Andréi, crítico, le indica que es un "mafioso». Pero la mujer ya lo sabe "y ¿qué más da?». Lo que le interesa es que debe conseguir 1.000 invitados, como él conoce a 200, debe conseguir 800 figurantes. Sueña con comprar un terreno en el campo y poder "cultivar nuestras propias verduras», para dejar de "pagar una fortuna por las hortalizas». Y le comunica, airada, que le han subido 100 rublos la pensión, pero el alquiler son 200 rublos. También las patatas se han puesto por las nubes.Todos y cada uno de estos rasgos nos presentan el mundo

ejemplo, y no todos los grupos son de etnia rusa ni sustentan ningún código de honor, aunque sí coinciden en que mafioso y grupos criminales «compran políticos para defender sus intereses» (Service, 2005, p. 349). 
post-soviético, y una parte (con sus estereotipos evidentes) del carácter ruso: autoritario y sumiso, en última instancia aguerrido y que busca la manera de superar las adversidades (resiliente), creativo, artístico, sincero y, por supuesto, borrachín (a veces, desde una perspectiva bucólica, fiesta con los gitanos; otras autodestructiva, cena con Anne-Marie).

Por un lado, en la figura de Andréi se representa a aquellos que sufrieron las represalias del régimen que no recuperaron sus antiguos puestos ${ }^{6}$, y cómo tuvieron que adaptarse. En general, los rusos se vieron afectados por las míseras pensiones (y sueldos), por la pérdida de los ahorros y un nuevo nivel de vida más inaccesible para los sectores desfavorecidos, en los que surgen tan curiosos empleos como el buscar figurantes para ciertos actos públicos, para los nuevos hombres fuertes del país: empresarios y mafiosos.

Aunque podría considerarse a simple vista un retrato simplista, el filme no trata de describir la sociedad rusa tal y como es, sino los elementos que se destacan más en ella, como una manera de ironizar sobre una realidad que desde las instituciones se dan por buenas, no dejando de ser una mirada no oficial (Ferro, 1995, p. 27), frente al discurso imperante que subraya las virtudes nacionales para encubrir las deficiencias del día a día de buena parte de la población, tal como nos mostrará la trama. $Y$ donde el cine, como retrato social y emocional, cobra ahí sus virtudes más elocuentes, como es el caso, ofreciéndonos un punto de vista distinto.

En suma, El Concierto recoge en pequeñas pinceladas parte de «las señales de una aguda crisis social, en la forma ante todo de distancias cada vez mayores entre pobres y ricos» (Taibo, 2017, p. 31), que se dieron en los años 90, pero que tampoco desaparecieron del todo en Rusia en las décadas posteriores. Una sociedad que, como recoge Matías, se lo tomó con un peculiar y sardónico humor negro, popularizando muchos chistes sobre la realidad social, incluidos contra antiguos dirigentes comunistas, menos sobre Stalin (de respetuosa figura), Yeltsin o Putin incluidos, contando con muchos portales en Internet dedicados al humor (Matías López, 2002, pp. 29-32 y Service, 2005, p. 385). Sin embargo, no todo el pasado ha sido borrado, puesto que todavía hay ciertas viejas élites que siguen estando al frente de los organismos del Estado (Service, 2005, p. 91).

El pasado soviético ha quedado, así mismo, para muchos como un viejo residuo (pero también como un elemento de decepción) ${ }^{7}$. De hecho, la buena de Irina convence a Andréi para que participe en otro acto en el que le ha fallado un figurante. Es una concentración que recuerda las glorias pasadas. De un primer plano de unas

${ }^{6}$ Sí hubo rehabilitaciones de individuos condenados por cargos falsos del periodo soviético, pero fueron a título póstumo y alcanzó a bastante poca gente de los cientos de miles de expedientes que se contabilizaron (Service, 2005, p. 94 y Gessen, 2018, p. 172).

7 Hay que pensar que el director huyó de la Rumanía de Ceaucescu y que su primer filme, Traidor (1994), fue un retrato de su país natal crítico con el comunismo. 
insignias comunistas, de una música triunfal y de un grupo de personas que parecen entusiasmadas, pronto, se abre la imagen para mostrar a un reducido grupo de personas, la mayoría gente mayor, que ondea viejas banderas soviéticas y porta algunos carteles con figuras emblemáticas del comunismo, que jalea a un antiguo líder comunista que con su micrófono les dirige unas palabras como si nada hubiese cambiado. Es Iván Gavrilov, un antiguo miembro del KGB ${ }^{8}$, entusiasta y entregado. «iEl pueblo está con nosotros! ¡La historia está con nosotros! ¡Caminamos hacia la victoria, de una ideología justa, juntos construiremos la mejor sociedad que el mundo ha visto jamás! ¡El comunismo! ¡Hacia el comunismo!». Y se ve respondido con un jaleo a sus palabras.

Pero una vez que ha concluido, negocia con Irina el precio de los figurantes que ha traído, entre los que ella misma está incluida. Gavrilov regatea con ella y le propone otro premio si acuden al domingo siguiente a la concentración. Irina, convenientemente uniformada con sus medallas del partido, se niega porque ya está harta de sus promesas. Con lo que el otro le espeta: «¿Acaso no crees en la causa?». E Irina, de forma tajante, le responde airada: «iNo creo y nunca he creído, Gavrilov! ¡Os podéis ir al carajo tú y tu partido!». Y le exige el pago convenido.

El hombre no tiene más remedio que aceptarlo, le da en mano el dinero y expresa su rabia: «jEs una explotación, una auténtica explotación!» ${ }^{9}$.

La escena representa muy bien, con fina ironía, en qué ha quedado el antiguo orden soviético (Service, 2000, p. 480) ${ }^{10}$, en una recreación terriblemente mordaz y burlesca. Se presenta como una reliquia del pasado. El tono humorístico queda muy bien codificado por el hecho de que un antiguo comunista debe pagar por lograr que haya participantes en sus manifestaciones y no se apague la vieja llama... pues la mayoría solo están ahí por el dinero, para llegar a fin de mes, ante sus mezquinas pensiones, y no porque crean en la causa (revelando, con ello, las miserias dejadas por el mismo sistema).

${ }^{8}$ La policía política fue el organismo de control social más importante en la época soviética. En 1973, componían el cuerpo 500.000 agentes, que subió a 700.000 para 1986, contaba con un listado de temas que no podían aparecer en la prensa y, por supuesto, eran los encargados de vigilar de cerca, controlar y atajar cualquier disidencia interna. Si bien, muy alejado, en sus prerrogativas, de la siniestra reputación adquirida por su predecesor, el NKVD, durante las purgas de Stalin.

${ }^{9}$ El mismo director del filme cuenta cómo fue testigo de una de estas concentraciones de nostálgicos soviéticos, que se celebraban todos los domingos en Moscú, y se le ocurrió introducirla. <https://www.lahiguera.net/cinemania/pelicula/5058/comentario.php> [consultado el 28/04/2018].

10 En noviembre de 1992, el Tribunal Constitucional ruso permitió la refundación del partido con la denominación Partido Comunista de la Federación Rusa, abandonando el internacionalismo, para pasar a reivindicar la memoria de Lenin y de Stalin. 
Por lo tanto, revela cómo, en realidad, apenas hay ya ciudadanos que se crean soviéticos. Antaño cumplían con este deber de acudir y asistir a las grandes marchas y celebraciones del partido, por obligación, y no porque hubiesen penetrado en ellos las consignas. Gavrilov representa, por eso, al viejo orden, que se niega a admitir que su mundo ha desaparecido y aún sueña con sus efímeras glorias.

El tratamiento que se hace, de todas formas, es un poco exagerado. Es verdad que el número de comunistas auténticos no era ya muy elevado, pero no estaba extinto, aunque no dejaban de ser una minoría en la Rusia actual (Matías López, 2002, p. 127); pero muchos añoraban «la situación social» (Taibo, 2017, p. 46) anterior, frente a un presente en el que se sentían totalmente indefensos frente al deterioro general de las condiciones de vida. En otros casos, en cambio, se muestra cómo viven refugiados en la nostalgia de lo que fueron porque no encajan o no han encontrado su lugar en el mundo poscomunista y no pueden recuperar el tiempo perdido. Así, la reunión de la Asociación de música de Moscú es en un restaurante, no cuentan con un local propio para hacerlo. Son un pequeño grupo entusiasta que actúa como si de verdad estuviera tocando música (no cuentan con ninguna clase de instrumento) y tararean la cabalgata de Guillermo Tell.

En ese encuentro, al que acuden Sacha y Andréi, también se nos muestra otro elemento social cuando uno de los músicos le ofrece a Andréi un vaso de vodka.

Él se mira la mano temblorosa, inquieto ante la tentación de recaer, lo que muestra su antiguo alcoholismo, y lo rechaza.

El problema del alcoholismo en la sociedad rusa desvela que muchos ciudadanos ahogaban sus penas en el vodka y otras bebidas, una manera de no sentir la dura realidad (Carrère, 2001, p. 43 y Meyer, 2009, p. 453). Esta lacra social no era novedosa, ya que fue un refugio muy tradicional de la época soviética. A pesar de las medidas que se tomaron para frenar la venta de vodka, estas sirvieron de poco (Service, 2005, p. 351).

En la misma escena, Andréi pide a Sacha, que ha estado con él en la concentración, que le acompañe para hablar en privado. Son viejos amigos. Le lleva hasta el baño y en ese singular lugar le da una carta y le pide que la lea. En ella está la propuesta del director del Châtelet, Olivier Morne Duplessis, de contar con la orquesta del Bolshói para dentro de dos semanas en París. Aunque Sacha, al principio, cree que es una broma porque está el fax escrito en ruso, Andréi le confirma su plan. Y le propone ir en el lugar del verdadero Bolshói y así cumplir el sueño de su vida. Para Sacha es una idea descabellada.Andréi le insiste en que los actuales integrantes de la orquesta del Bolshói son muy malos, «nosotros somos mejores». Es un reflejo de cómo esta orquesta forma parte ya de "un mito en decadencia» (Matías López, 2002, p. 37), a nivel artístico.

Así, volviendo al filme, Andréi tiene claro lo que persigue, a pesar de todas las pegas que le pone Sacha: «Llevamos 30 años sin tocar, somos unos infelices ¿dónde vas a encontrar una orquesta? No tenemos sala de ensayo, no tenemos ni un cén- 
timo y no hay tiempo para formar una auténtica orquesta. Encontrar 80 músicos en quince días. Te has vuelto loco de repente. Y ¿por qué no bailarines de paso?». Pero Andréi lo tiene claro: «Solo necesitamos 55 músicos», que son los integrantes mínimos que se requieren.

No se trata, en suma, solo de una cuestión musical sino de redención, como se irá viendo. Una muestra de orgullo artístico y humano (en definitiva) que pretende rebelarse contra la adversidad y la resignación que se han impuesto tras el colapso de la URSS, en donde la música va a adquirir un elemento alegórico liberador muy importante.

Pero para encontrar su futuro, necesitan del pasado (a Gavrilov).

Desplazándose en la destartalada ambulancia de Sacha, que subraya esa precariedad y deterioro material existente, vemos cómo se acerca a la Sede del Partido Comunista, que ahora se halla en un piso. Sacha intentará todavía, antes de entrar, hacer desistir a Andréi, de su descabellado proyecto. Y le indica que, de todas formas, en cuanto llamen al Bolshói desde París todo se irá al traste. Pero Andréi está convencido de lo que hace y le responde: «iNo si antes no lo hacemos nosotros!». Y en cuanto Sacha descubre a dónde le ha guiado Andréi tampoco le gusta. Van a encontrarse con Gavrilov, que tuvo un papel muy relevante en su expulsión y amargo destino. A pesar de todo, Andréi lo describe como el mejor representante de Moscú y que habla el francés mejor que Molière. Sacha pretende inútilmente razonar con Andréi y le recuerda que fue él quien arruinó sus respectivas carreras. Andréi lo modera contestándole justificativamente que "cumplía órdenes». El otro le replica airado: «¡Eso no es verdad! ¡Salió al escenario en mitad del concierto para violín de Tchaikovski delante del público y lo detuvo para humillarte! ¡Es un demonio! iSe divirtió haciéndolo!». Y, finalmente, cuando llegan al piso, Sacha le expresa con negra ironía: "Yo no entro. Nadie ha podido salir dos veces de una dictadura comunista». Entonces, Andréi le responde: "Sacha, ¿quieres volver a tocar el violonchelo? ¿O, prefieres conducir una ambulancia toda tu vida? Iván Gavrilov nos debe un concierto. ¡El Concierto!». Sacha no puede decirle que no, aunque todavía no sabemos por qué causa Andréi exige el pago de la citada deuda.

Siguiendo con la escena, Andréi irrumpe y directamente le lanza a Gavrilov la propuesta de convertirse en el manager de nuevo. Este, que habita un pequeño despacho lleno de libros, con un cuadro de Lenin apoyado en el suelo y otros símbolos comunistas, le responde con acritud: «¡Buenos días para empezar!». Andréi le intenta explicar su plan y el otro no sabe a qué orquesta se refiere. Hasta que Sacha lo agarra de las solapas y le levanta de la silla para gritarle: «iLa puta orquesta que destruiste hace 30 años! iY a la que arruinaste la vida! ¡Desgraciado!», mientras Andréi se esfuerza en separarlos. Sacha le reprocha todos los viajes que les prohibió. Y el otro, igual de airado, le replica: «¡Hace treinta años habríais pedido asilo político hasta en la Patagonia! iSí, para una vez allí traicionar a vuestra madre patria y criticar en la prensa imperialista al país que os había criado, dado de comer y mantenido! ¡Yo tenía mis propios informadores!». Estos comentarios muestran 
muy claramente esta dura realidad, a veces tan asfixiante, que se vivía en los peores tiempos de la URSS ante el temor a las deserciones.

Sin embargo, el otro, furioso, replica: «¿De qué mierda de madre patria me estás hablando? ¡Cabrón! ¡Fuimos degradados, destrozados, humillados y después nos echaron! ¡Por tu culpa, tú hiciste que nos expulsaran!». Finalmente, Andréi, tras mucho esfuerzo, logra separarlos. Sacha insiste en achacarle los fracasos de su vida, incluido que su mujer y sus hijos le abandonaran. Pero el otro le replica que fue por su culpa porque no quiso irse a Israel con ellos, "a su país». Pero para Sacha su país es Rusia, de ahí que no se fuera con su familia. Esta conversación anticipa una de las claves del filme: la política soviética respecto a los judíos y una historia marcada por la tragedia.

Pero, al mismo tiempo, puede interpretarse como una metáfora de cómo el comunismo (Gavrilov) acabó con parte de la cultura rusa (Andréi y el concierto de Tchaikovski), en sus obsesiones ideológicas contra los imaginarios enemigos del pueblo.

Debemos considerar que, aunque el nazismo se empeñó en inventarse un concepto falso, el judeo-bolchevismo, en el seno de la URSS los judíos no estaban bien vistos, a pesar de lo que sufrieron y su persecución. Al poco de la muerte de Stalin, el antisemitismo volvió a «tener beneplácito oficial» (Service, 2000, p. 394). Y Brezhnev no dudó en facilitar la emigración de miles de ellos a Israel, precisamente, lo que hará la familia de Sacha. En los años 70, mostrando así que la minoría judía no se sentía bien integrada en el país de los Soviets, emigraron nada menos que 100.000 judíos a Israel, aunque cerca de la mitad de ellos acabaron en EE. UU. o en la RDA, hasta que en 1979 se volvieron a cerrar las fronteras tras la no ratificación por parte del Congreso de los EE. UU. de los acuerdos nucleares Salt II (Bayón, 1983 y Meyer, 2009, p. 458).

A pesar de que Brezhnev alardearía del nacimiento de una «nueva comunidad histórica de pueblos: el pueblo soviético» (Taibo, 2000, p. 29), y de crear al homo sovieticus (Carrère, 2001, p. 30 y Gessen, 2018a, pp. 65-86), la realidad fue muy diferente, y los judíos no encajaban en ella (viéndolos, muchas veces, como agentes extranjeros). De ahí que la película reivindique a los judíos como parte de la sociedad rusa, menospreciados y discriminados, perseguidos incluso, y detenidos. Ello nos lleva a preguntarnos si el director no denuncia, como una metáfora más general y recurrente, la nueva xenofobia de los rusos hacia las poblaciones étnicas no rusas. Aunque también podría ir más lejos y sintetizar de una forma muy rotunda la persecución y el todopoderoso control social que se ejercía en la sociedad soviética a lo largo del periodo.

Esta conexión entre pasado y presente, sin duda, parece rechazar las políticas gubernamentales intolerantes, en el contexto de su filmación ${ }^{11}$. Pero, al mismo

${ }^{11}$ Claro que habría que matizar que la comunidad judía en Rusia, a partir de aquella persecución, se ha visto beneficiada por la tolerancia religiosa vigente, aunque eso no ha evitado 
tiempo, es difícil señalar si también era una manera de desmitificar la época de Brezhnev que tanto acabaron idealizando los rusos a finales de los años 90, por considerar que fue una época "estable y predecible» (Service, 2005, p. 127), olvidándose de la negativa percepción que tenían de ella una década antes. En suma, se fantaseaba con un periodo que se valoraba como confortable, frente a la espiral de cambios provocados por el fin de la URSS, sin darse cuenta de que sus consecuencias venían ligadas a este.

En el filme, tras tanta tensión, Andréi logra mostrarle a Iván la carta de París y convencerle de que les ayude en sus propósitos de organizar el concierto haciéndoles pasar por el Bolshói. Porque los verdaderos, le espeta, «tocan con los pies». Y le aprieta en su orgullo: «¿Te imaginas los titulares de la prensa francesa?». Eso hace reaccionar a Iván. Y Andréi insiste: «Seguro que dirán, las orquestas rusas están sobrevaloradas, no son ni sombra de lo que eran. Como rusos ¿vamos a dejar que eso ocurra?». Y esa apelación nacionalista parece hacer mucho efecto en su amor propio. Además, a Iván le atrae el hecho de que sea en París, pero duda de por qué le ha elegido a él. Andréi le aclara que para que se encargue de negociar como «en los viejos tiempos». Y vuelve a apelar a su vanidad expresándole que él ha sido el mejor manager del Bolshói. Iván sorprende a ambos aceptando. Aunque Sacha desconfía y quiere saber el precio que les pone por hacerlo. El otro les responde que nada, tiene sus propios intereses personales, una ingenua percepción de que todavía se puede revitalizar el sueño comunista europeo.

Por si acaso, Andréi le ofrece conseguirle un carné de antiguo combatiente para que pueda viajar gratis en los trasportes públicos. Como tan indicativamente escribe Service y queda aquí recogido: "Las arbitrariedades administrativas y la falta de honradez no han desaparecido" (Service, 2005, p. 376). De hecho, ya lo tiene. $E$ insiste en que lo hará sin exigencias ni condiciones. Cuando se marchan, extrae de su escritorio una gruesa carpeta roja en la que se lee en letras rusas: París. Ahí está su propio plan.

Una vez en casa, Andréi se lo cuenta a su mujer. Aunque no le agrada la idea de que vaya Gavrilov, finalmente le dice: "Andréi, pediré el divorcio...», lo que hace bajar la mirada a este porque sabe que sin su consentimiento no lo hará, "como no vayas a París. Demuéstrame que sigues siendo el Maestro y que puedes dirigir hasta el final ese maldito concierto. 30 años. He estado esperándolo ¡30 años!». Y le hace un gesto expresándole su apoyo. Esa misma noche, Andréi hurga en una vieja caja llena de partituras y recuerdos. De entre ellas extrae una de Tchaikovski. Y rememora aquellas dolorosas imágenes cuando vio su concierto interrumpido por Iván, rompiendo de forma abrupta su batuta ante sus narices y acusándole de ienemigo del pueblo!Estas imágenes nos muestran ese bloqueo emocional que ostenta

tampoco la persistencia de un antisemitismo popular en la sociedad ni la emigración de cerca de un millón de judíos a Israel (Service, 2005, pp. 260-261). 
Andréi. A pesar del tiempo transcurrido, la realidad es que la memoria pesa mucho en nosotros. En este caso, es un trauma personal, metáfora de todos aquellos que sufrieron alguna persecución, que todavía siguen prisioneros, en cierta manera, de esa deuda moral.

Siguiendo con su plan, Sacha y Andréi hacen entrar a Iván secretamente en el teatro Bolshói, gracias a que Andréi, como conserje, dispone de todas las llaves. En su oficina, Andréi extrae un teléfono clandestino, por el que Sacha puede hablar con su familia en Israel. Iván se enfada porque no paga y le reprocha que ese teléfono pertenece al Estado y al pueblo. Y saca a relucir los viejos y caducos eslóganes comunistas, una paradoja a tenor de la farsa que se ha animado él mismo a representar.

Finalmente, se pone en contacto con Oliver, el director del Châtelet. Mientras los tres conspiradores se hallan en un cuartucho en los bajos del Bolshói, al director del Châtelet le encontramos en un amplio, luminoso, moderno y precioso despacho de paredes níveas. Cuando el francés quiere saber cuál será el programa del Bolshói, Andréi le dice sin dudarlo: Tchaikovski, el mismo concierto que quedó inacabado; Andréi busca tan solo cerrar aquella herida abierta que todavía tanto le duele.El hecho de que se elija al músico ruso Tchaikovski como emblema es muy simbólico, ya que el autor fue el impulsor del renacimiento de la música rusa en el siglo XIX junto a Glinka y los kuchkistas ${ }^{12}$, «modelo para toda la música futura de la Unión Soviética» (Figes, 2006, p. 574). Su figura se erige actualmente delante del mítico Conservatorio, considerado como «la catedral musical de Moscú» (Matías López, 2002, p. 35). No es baladí en la idea de convertirse en un icono cargado de alegoría histórica.

De hecho, Tchaikovski fue muy criticado en su época porque su estilo era más occidental que eslavo, e implica otra alusión importante a la necesidad que tiene Rusia de salir de su propio caparazón y mirar al mundo. Tal y como indica Figes, «las grandes figuras culturales de la tradición rusa», en la que incluye a este compositor, «no eran solamente rusos, también eran europeos» (Figes, 2006, p. 33).

Esta escena anterior vuelve a explorar otros aspectos que el director quiere remarcar sobre Rusia. El contraste material entre la sociedad francesa y rusa, una moderna y otra que parece anclada en un tiempo anterior, dos décadas atrás, se verá confirmado, no solo por la forma de vestir de Andréi o Sacha, sino por el detalle de los salarios que piden al Châtelet por actuar e, incluso, por el vetusto francés de Gravrilov (que en el doblaje en español no se aprecia demasiado) ${ }^{13}$. Siguiendo

12 Se denomina al círculo de compositores rusos, integrado por Mili Balákirev, César Cuí, Modest Músorgski, Nikolái Rimski-Kórsakov y Aleksandr Borodín, que en el siglo xix impulsaron un estilo de música que consideraron específicamente rusa.

13 <https://www.lahiguera.net/cinemania/pelicula/5058/comentario.php> [consultado el 28/04/2018]. 
con la trama, confirmado todo en casa de Andréi, Iván se encarga de preparar el viaje, las dietas que van a pedir, los seguros y los días de estancia allí. Sacha, en un aparte, le confiesa a Irina las intenciones de Andréi de tocar a Tchaikovski, pero ella ya se lo ha imaginado. Y exclama: "Y tú le ayudarás». Mientras, Iván, a pesar de su vanidad ideológica y cultural, vive anclado, como Andréi, pero de otra manera, en una época distinta. Por eso, ahondando en el tono de parodia dramática, exige habitaciones en un hotel que considera que es el mejor de París, el París Lumiére, de tres estrellas. No deja de ser un lugar bastante mediocre. También se van a encontrar con una gran sorpresa durante la cena en el restaurante Le Trou Normand. Por supuesto, queda para el final lo más importante, quién será la solista del concierto. A Andréi se le ilumina el rostro y pide a una música de reconocido prestigio internacional: Anne-Marie Jacquet. Aunque Sacha afirma que eso es demasiado, Iván cree lo contrario: «Tenemos que ser exigentes y caprichosos, eso da una imagen sólida y profesional». Pero la verdad es que para el director del Châtelet las pretensiones de la orquesta no son ni remotamente altas y señala muy significativamente: "Parece que se han quedado en los sueldos de antes de la Perestroika».

Una vez más, se enfatiza cómo Rusia parece haberse quedado varado en un limbo atemporal, entre el fin de la era soviética y un difuso presente, viéndose no solo en sus bajas pretensiones económicas, sino en lo poco que saben hasta qué punto ha avanzado el mundo que les rodea. Un énfasis que se pone de relieve en el modo que tiene de hablar Gavrilo en un francés arcaico y pretensioso.

Todo depende de Anne-Marie. Claro que, en casa de la solista, la asistenta de esta, Guylène, rechaza, en primera instancia, la propuesta del director, sin saber que ella le ha escuchado. Pero Anne-Marie, que está en otra habitación, la interroga, acabando por descubrir la verdad: que la han llamado del prestigioso Châtelet para tocar con el Bolshói y a Tchaikovski. Guylène intenta desviar la atención cambiando de tema. Pero la llama ha prendido en ella. Porque Anne-Marie sueña «con el concierto de Tchaikovski, con el Bolshói». Aunque Guylène insiste en no darle importancia, ya que estima que ni el director es conocido ni tampoco «el Bolshói es lo que era». Pero al revelar que el director es Filipov, Anne-Marie sabe quién es, no es cualquier director, "es el maestro. Ese hombre es una leyenda y Tchaikovski con él».

Pero la otra le indica que lleva 30 años sin dirigir. Anne-Marie no le escucha y le pide que llame para aceptar las condiciones que sean. Por lo que Guylène no tiene otro remedio que llamar y confirmar su participación. La elección de Anne-Marie encierra un gran secreto. Las piezas van encajando, entre el humor, el melodrama y la ironía, Mihaileanu va allanando el camino hacia un sutil y hábil propósito redentor. Una valoración de lo importante que es la memoria de las dictaduras y su confrontación.

Volviendo a Moscú, Andréi extrae de una caja sin etiquetar un artículo sobre ella y CD con sus actuaciones. También la batuta rota de aquel fallido concierto... Así que, pese a lo impensable, Andréi ha logrado salirse con la suya. Ahora queda 
buscar los integrantes de la orquesta que se harán pasar por el Bolshói. Y para eso, acompañado por Sacha, recorren toda la ciudad llamando a todas sus viejas amistades. Lo que es una oportunidad parar mostrarnos otros aspectos de la sociedad rusa.

Lo primero que hacen es acudir donde un viejecito, Viktor, que nada más abrir la puerta se sorprende y expresa a su mujer de forma elocuente: «iDios mío! Rivka, mira quién está aquí. El hombre que se atrevió a mandar a la mierda al mismísimo Brezhnev ${ }^{14}$ ».

Les hacen pasar y el hombre les recita con su trompeta unas notas. La anciana pareja parece haber vivido encerrada, desconociendo cómo ha cambiado el mundo. Y quiere saber si en París aprecian a los judíos (imaginamos que es un emigrado francés de la SGM) (Burrin, 2004) $)^{15}$. Sacha le disipa sus dudas afirmando, muy exageradamente, que allí hay más sinagogas que iglesias. Incluso que los «católicos franceses se han vuelto todos laicos». La señora pregunta por Notre Dame, y Sacha sin pudor les dice que ahora la famosa catedral es «judía por fuera y católica por dentro». Tras estas explicaciones la mujer da la confirmación a Viktor para que vaya. Viktor va más lejos y señala que irá por Andréi, porque lo considera un «Justo»" ${ }^{16}$ y además le acompañará su hijo Moshe, que también toca la trompeta como él. No hay duda de que la familia parece enclavada en un pasado remoto, ajena a los cambios sociales y culturales dados en Europa.

A continuación, se dirigen a una fábrica abandonada, vestigios del pasado industrial. Dentro se está grabando el doblaje de películas pornográficas, donde otro músico que buscan se halla tocando el clarinete. Esto ilustra muy bien otra faceta de la sociedad rusa como es el consumo y expansión de este mercado, frente a las restricciones existentes en los tiempos anteriores (Service, 2005, p. 390). En otro barrio, también poco cuidado y destartalado, se les suman otros tres componentes, que ahora hacen de trasportistas. En un mercado, fichan a dos hombres que, en su día, imaginamos, formaron parte del Bolshói y ahora venden fruta; una mujer que trabaja en un museo, un taxista, aunque no todos le dicen que sí, quieren participar.

Así, Andréi va poco a poco completando un cuadro que se ha hecho con las posiciones de la orquesta que está formando.

${ }^{14}$ Leónidas Brezhnev (1906-1982). Estuvo al frente de la URSS desde la destitución de Jrushchov hasta su muerte. Los últimos años estuvo muy enfermo. Encarna la época de decadencia de la sociedad comunista, antesala del reformismo de Gorbachov, de ahí seguramente su utilización como referencia en el filme.

15 Pues las autoridades de la Francia de Vichy colaboraron activamente en estos años con los nazis en la persecución judía. Tal vez, por ello, este personaje tenga todavía reticencias a volver a París, ante el recuerdo de aquellos terribles hechos.

${ }^{16}$ Se refiere a todos aquellos de confesión no hebrea que merecen toda consideración o respeto, sobre todo, destinado a honrar a todas aquellas personas que ayudaron a salvar a los judíos de la persecución nazi. 
Aunque estas instantáneas no pretenden ser una radiografía social exacta, sí nos dejan patente un muestreo, con cierto aire extravagante y cómico, de la herencia mísera del fin de la URSS para muchos ciudadanos. Tal fue su impacto que, de hecho, se incrementaron el número de suicidios, de alcoholismo y desesperación. El director juega, con todo ello, en su fresca lectura, con la ironía y la exageración en las actividades que desarrollan los integrantes de la orquesta, para hacer más digerible una realidad sórdida y amarga, en la que tantos millones de rusos tuvieron que buscarse segundos empleos, comerciar en la calle o, incluso, trabajar en condiciones serviles. A lo que habría que añadir un sinfín de mendigos, muchos son jubilados, personas con discapacidad física, alcohólicos o madres sin hogar con niños viviendo en condiciones pésimas y sin ayuda (Matías López, 2002, pp. 173-178 y Service, 2005, pp. 352-355 $)^{17}$.

Siguiendo con la trama, finalmente, para acabar de completar la orquesta, acuden a un campamento de gitanos, a las afueras de Moscú, otro guiño a la cultura rusa.

Fuegos, neumáticos usados, caravanas y tiendas de campaña nos desvelan la precariedad de sus vidas. Sin embargo, esconden excelentes cualidades artísticas. Y uno de ellos, Vasili, desvela su maestría con el violín. Se enciende a tocar y eso provoca que Sacha, Andréi y el campamento gitano entero se pongan a bailar.

No parece gratuita esta escena, pues se trata de un referente muy importante de la literatura eslava, y escritores tan reputados como León Tolstói, Fiódor Dostoievski o Máximo Gorki, describían como parte de un exotismo nacional ruso escenas con «largas noches de borracheras en campamentos gitanos» (Service, 2005, p. 75).

Pero, a pesar de todo lo que ha logrado con tan poco, Andréi, abrumado por la responsabilidad, se halla nervioso sabiendo que se les echa el tiempo encima y todavía le falta encontrar a varios integrantes importantes para completar la orquesta. Sin embargo, Sacha le anima y le insiste en que lleva a Tchaikovski en la sangre y le reprocha que ya están hartos tanto Irina como él. Por eso, le insta a ir a París para que se libere de una vez. Pues la obsesión de Andréi es clara. Conseguir acabar aquel concierto que le persigue como una alargada sombra a lo largo de estos 30 años. La autocompasión se configura, así, como parte de esos rasgos de la personalidad típicamente rusa.

Otro aspecto muy conseguido a la hora de mostrarnos cómo es la actual sociedad rusa viene marcado en la escena en la que asisten a un convite de boda. Irina se ha encargado de llevar a mil figurantes a la boda de Genkin, un mafioso conocido. Entre los invitados se hallan Andréi y Sacha que acuden para cubrir la cuota. El contraste social entre la vida de la madura pareja, o la áspera situación de los demás componentes de la orquesta, es evidente, mientras los protagonistas

17 Donde muchos rusos acabaron suicidándose ante su desesperada situación en los años más duros de la crisis que afectaba a la población. 
malviven, defenestrados por ser detractores del viejo régimen o por una economía que los lleva a ganar unos pocos rublos, otros hacen gala de una ostentación de mal gusto y practican un generoso despilfarro.

Se nos describe, en una hábil panorámica, un gran banquete nupcial, nada especial, si no fuera por la contratación de los invitados y la ambientación seudohistórica de estilo clásico. El lugar pretende recrear un antiguo teatro romano, con su graderío, falsas columnas y fachadas de templos. En el escenario, toca un grupo musical pop. Unas jóvenes amazonas pasean a caballo, hay varias figurantes vestidas de soldados romanos que llevan a cabo la pantomima de una batalla a espada. La joven novia disfruta mientras los invitados le ofrecen sobres con dinero y varios cámaras graban, como si se tratase de un evento digno de conservarse para la posteridad. Las mesas están ricamente decoradas, con cristalería fina y candelabros y varias camareras, vestidas con motivos romanos, acompañan a los comensales a sus mesas. Entre ellos también están varios de los amigos músicos de Andréi. Todo ello nos lleva a valorar un ceremonial que contrasta y mucho con aquella mítica escena del filme El Padrino (1972), de Francis Ford Coppola, de la boda de Sonny Corleone. Mientras aquella es discreta e íntima, describía con puntilloso acierto los rituales tradicionales y familiares de respeto y lealtad tan italianos, en El Concierto es todo lo contrario, lujo, mal gusto, ostentación y violencia.Enfatizando ese lado cómico, Andréi aprovechará la ocasión para intentar fichar a algún otro músico, aunque no le hacen demasiado caso, pues creen que ha estado bebiendo... Entre tanto, harán entrada dos coches, de uno de los cuales baja Makarov, otro mafioso, con cara de pocos amigos, y sus guardaespaldas. Irina explica a los integrantes de la mesa que este está enfadado porque a su boda solo fueron 500 invitados, y no los 1.000 que ha podido reunir su rival. Desvela, por tanto, la egolatría y el talante pretencioso de esta nueva élite mafiosa. Claro que cuando las cosas no podían ir peor, hace acto de presencia Gavrilov, quien se ha colocado en la fiesta para informar a Andréi que París ya no adelanta el pago de los billetes de avión. Deben hacerlo ellos. Sacha le recrimina a Gavrilov que lo que quiere es sabotear el concierto. E Irina le lanza la idea de que consiga un sponsor entre los invitados. Pero el otro, no sin razón, les indica que estos no invierten en música sino en «comprar equipos de fútbol». Y añade, «no les interesa una mierda, no da dinero, se puede bajar gratis de Internet». Estas frases responden muy bien a la verdad, sobre la que volveremos un poco más adelante.

Sin embargo, Irina reacciona enfadada ante sus pegas y espeta al exKGB: «iCállate, Gavrilov y escúchame! ¡Hace 30 años, cuando hiciste tu número en pleno concierto de mi marido y lo convertiste en borracho, destrozaste su vida! ¡Y cuando nos quedamos sin nada y cuando perdimos incluso nuestros mejores amigos, no dije nada, me equivoqué! ¡O sea que ahora cierra la boca y no nos cuentes historias porque te cortaré los cojones y los pondré en un plato!». Y no solo eso, le insiste en que o encuentra un patrocinador y los lleva a París, o si algo sale mal, le recomienda 
que pida asilo político, porque se encargará ella de que no pueda contratar extras y tendrá que acudir solo a sus manifestaciones. Y le advierte, al final, que jamás vuelva a hacer daño a Andréi.

Gavrilov se ve claramente intimidado por la filípica de Irina.

Aunque el filme no se adentra en este tema, ante la presencia de las jóvenes chicas que animan la velada, habría que indicar que la situación de la mujer en Rusia es de profunda desigualdad tanto en el hogar (con abusos y maltrato) como en la esfera pública, peores sueldos (ya venía de la época anterior) y no pocas veces, como se muestra, aparecen como meros objetos sexuales ${ }^{18}$. Y mientras para acallar la melancolía, los hombres se refugian en el vodka, un elemento muy recurrente en la trama, las mujeres no. "Sin las mujeres, todo el orden social se hundiría. Así ha sido siempre» (Service, 2005, p. 359).

La firmeza de Irina es un claro ejemplo de ello, mientras los hombres viven con sus obsesiones, son las protagonistas las que se han enfrentado mejor a la realidad.

Así mismo, como se ha podido ir viendo, el antiguo KGB ya no es aquel todopoderoso funcionario que no admitía réplica. De hecho, «en tiempos soviéticos, la sola mención del KGB o de sus antecesores infundía pavor» (Matías López, 2002, p. 112). Pero ahora, ya, no. Y la actitud de Gavrilov lo demuestra. Conserva sus viejas ínfulas de comunista irredento, aunque no puede hacer nada contra la furia de Irina. Es ficción, sin duda, pero también encarna bien el fin de su poder, sustituido, eso sí, por otros diferentes.

De nuevo, justo cuando concluye de hablar Irina, el mafioso Genkin, muy borracho, tras saludar a un ministro y a varios integrantes de la Duma, presenta en el escenario a un joven y rico empresario, lo anuncia muy significativamente como el zar del gas y el rey del cobalto, al que denomina el mejor violonchelista del planeta, Piotr Tretiakin. Pero cuando se pone a tocar la cara de interés de Andréi se disuelve en un gesto de amargor. Es un pésimo músico. En cuanto a lo señalado antes, no son casuales esos gestos de cordialidad a integrantes de las instituciones públicas, ni tampoco presentar a Tretiakin como «zar del gas y rey del cobalto», porque introduce así ese otro grupo (además del mafioso) que iba a caracterizar a la Rusia post-comunista, el surgimiento de una oligarquía empresarial ${ }^{19}$ (que iba a sustituir a la vieja nomenkaltura soviética a la hora de controlar los resortes del poder) que hizo formidables fortunas «al calor de fraudulentos procedimientos de privatización de algunos de los segmentos más golosos de la economía pública de antaño, y en particular de los vinculados con el sector energético» (Taibo, 2017, p. 35), como es

18 La cultura machista es dominante, así en la prensa suelen aparecer mujeres desnudas e, incluso, se emitía un programa de televisión en al que la chica del tiempo se desnudaba a la par que iba anunciando la meteorología. Si bien se han constituido un partido femenino, Mujeres de Rusia, y diversas organizaciones que buscan, después de todo, alterar estos roles imperantes.

${ }^{19}$ Como los oligarcas Román Abramóvich, Piotr Aven, Vladímir Gusinski, Mijaíl Jodorkovski, Vladímir Potanin y Anatoli Chubáis. Aunque algunos caerían en desgracia con Putin. 
el caso, y que, además, hasta la llegada de Putin resultaban ser intocables (Hoffman, 2003 y Service, 2005, p. 347).

Todo ello nos muestra que la ficción es capaz de transferirnos con eficacia claramente aspectos simbólicos de la realidad a la que alude.

De hecho, si la revista Forbes, en el año 2000, no recogía ningún millonario ruso, para el año 2013 recoge 110, los cuales controlaban nada menos que el 35 por ciento de la riqueza de todo el país (Taibo, 2017, pp. 36-37) ${ }^{20}$. Como expresa tan claramente Service: «Un capitalismo de la clase más primitiva se ha ensañado con Rusia: lo ricos se han hecho más ricos y los pobres más pobres y más numerosos» (Service, 2005, p. 341). Eso sí, debiéndose limitar a la esfera de lo económico y dejando clara su no injerencia en la alta política, o sufriendo, si no, las consecuencias (Claudín, 2011, p. 18).

En la misma escena, para mostrar las excentricidades de estas personas con poder o dinero, pero carentes de cultura, Genkin se pone a tocar una guitarra eléctrica animando a su amigo, y ambos producen una impresión espantosa, sobre todo, para los delicados oídos del maestro, dando un espectáculo entre patético y bochornoso.

En ese instante, llaman a Gavrilov por el móvil, que grita de forma desaforada que quiere Le Trou Normand para cenar, una de sus condiciones para ir a París. Pero sus gritos Ilevan a que Genkin y Tretiakin dejen de tocar y le miren directamente con visibles aires de enfado por su interrupción. Dos guardaespaldas se acercan donde Gavrilov con no buenas intenciones, radiografiando, así, un nuevo miedo social, ya no contra los antiguos servicios de seguridad, venidos a menos como él, sino contra las mafias empresariales que imponen su autoridad y no dudamos que de forma brutal (Gessen, 2018a, p. 158).

Enfatizando esta atmósfera decadente y ultraviolenta, no sin algo de exageración, el último mafioso en llegar, Makarov, está tan borracho que coge a la novia, igual de afectada por el alcohol, y la tira encima de una mesa para besarla imperiosamente. Eso provoca la iracunda reacción de Genkin que le estampa la guitarra en la cabeza y comienza un virulento tiroteo entre la guardia de los dos mafiosos ${ }^{21}$.

Por supuesto, todo esto origina un caos y un desorden tremendos. Con habilidad, se introduce un momento cómico, pues Gavrilov aprovecha para intentar convencer al multimillonario Tretiakin para que patrocine la orquesta. $Y$ vemos a los dos gateando por el suelo mientras intentan evitar que les alcance alguno de los disparos de esa ensalada de tiros protagonizada por los dos grupos mafiosos rivales. Otro instante jocoso, completando el anterior, sucede poco después, cuando Sacha y Andréi van a la enorme mansión del magnate para cerrar el acuerdo de patrocinio de la orquesta. Se desarrolla en un enorme salón con una estrafalaria escultura.

\footnotetext{
20 O lo que es lo mismo, el 0,00008 por ciento de la población.

${ }^{21}$ Nada inhabitual, por otro lado (Matías López, 2002, p. 153).
} 
Los dos amigos reciben de manos de Tretiakin un jugoso cheque que les permitirá lograr su propósito. El magnate, triunfal, le dirá a su anciana madre: «iVes, mama! Las clases de violonchelo han merecido la pena». Pero esta le recrimina que toca muy mal y que lo mejor que puede hacer es comprar un club de fútbol: «El PSG no está nada caro. Y compra también a Messi y ponle de atacante ${ }^{22}$. Una frase que parece exagerada, pero no lo es tanto, pues casa muy bien con el análisis de Service: "Los rusos acaudalados alardean de sus riquezas de la forma más grosera»; y añade más adelante, reflejando muy bien al personaje, nada caricaturizado, de Genkin, que «su deseo de aparecer como miembros cultivados del mundo de las finanzas internacional no pasa de ser una broma» (Service, 2005, p. 345).

Claro que, a la salida de la mansión, Sacha y Andréi se quedan consternados cuando el millonario le pide a Andréi la partitura del concierto, porque para él va a ser todo un honor tocar en su orquesta. Un detalle que Gavrilov no se ha atrevido a confesarles, por eso no es capaz ni tan siquiera de mirar a los ojos a Sacha y Andréi. Tretiakin expresa que se siente más un artista que un empresario. $Y$ les trasmite con tremendo entusiasmo que esto «es lo más importante de mi vida». Una vez en la ambulancia, el pobre Andréi estalla expresando su desazón contra la posibilidad de que Tretiakin toque en la orquesta: «iYo soy músico, no voy por ahí haciendo ruido!» y, añade: "ivamos a ser el hazmerreír de todo el mundo!».

Por eso, le pide a Sacha que dé la vuelta para devolverle el cheque. Pero este se niega, después de todo, han logrado lo que se proponían.

Ambas secuencias, tanto la de la boda del mafioso, cuyos vínculos con la política son evidentes, como esta en la mansión del estridente magnate con ínfulas de artista, encarnan ese dibujo irónico del capitalismo-mafioso que se perfiló en Rusia tras el fin de la URSS. A finales de los años 90, se estimaba que las mafias controlaban entre el 40 y el 60 por ciento de las transacciones comerciales (Taibo, 2017, p. 30).

Incluso, tal y como señala Matías López, «la frontera entre lo legal y lo criminal era difícil de trazar en la práctica, y las mafias estaban infiltradas en negocios clave» (Matías López, 2002, p. 147) en miles de empresas tanto estatales como privadas. $Y$, lo que es peor, tal y como se ha mostrado en el propio discurso del mafioso en el filme, «mantiene una relación estrecha con el poder político» (Matías López, 2002, p. 148).

Todo esto originado e inducido por un proceso de privatización bastante fraudulento motivado por la quiebra del modelo soviético, en el que antaño era el Estado el único dueño de los medios de producción. A la sombra de esta rauda apertura hacia un sistema de economía nace esta nueva oligarquía de magnates. Estos se

22 Este consejo de su madre se inspiraría en la figura del millonario ruso Román Abramóvich quien, con tan solo 36 años, compró un equipo inglés por 200 millones de euros (Fernández, 2003). 
iban a construir grandes viviendas en el campo, como la que se ilustra en el filme, alcanzando un nivel de renta altísimo, que les llevó a tener que contratar guardaespaldas ante el temor de que secuestraran a sus hijos (para pedir suculentos rescates) e, incluso, no dudaron en contratar asesinos en los años 90 para acabar con la vida de sus rivales financieros cuando eso servía a sus propios intereses (Service, 2005, p. 343) 23 .

Así y todo, cuando lo imposible se ha hecho posible, aparecen más inconvenientes para los protagonistas de la trama. Gavrilov les informa que, desgraciadamente, ninguno de los músicos tiene pasaporte ni visado y que lograr ambos supone esperar un tiempo del que no disponen para obtenerlos. Al menos, les comuni$\mathrm{ca}$, han logrado la reserva en Le Trou Normand. Así que, a grandes males, grandes remedios, y acuden a Vassili, que les puede conseguir en 24 horas los pasaportes que necesitan. Eso sí, han de pagarlos. Gavrilov, todavía metido en su papel de buen comunista, le señala: "No somos millonarios, somos el pueblo». Si bien, Andréi acepta pagar sin dudarlo.

Los dos momentos siguientes, antes de viajar a Francia, son igual de reveladores sobre otros aspectos de esta radiografía sarcástica de Rusia.

Tras haber cerrado el acuerdo con el Châtelet, conseguido el sponsor y solventado el tema de los pasaportes, una mañana luminosa, junto al Kremlin, se reúnen confiados los diversos integrantes de la orquesta. Parece que Andréi va a lograr su sueño. Pero los autobuses que ha contratado Gavrilov que, supuestamente, les iban a llevar al aeropuerto de Moscú no llegan. Este, como sabía que podía ocurrir, les ha reunido muchas horas antes del vuelo. Así que los pobres se dirigen andando hasta allí. En la terminal, les aguarda Vassili con toda su familia preparada para entregarles los pasaportes.

La orquesta hace cola, mientras van pegando las fotografías en los mismos, recibiéndolos en esta improvisada oficina ilegal. Vassili no desaprovecha la ocasión para ofrecerle a Viktor y a su hijo, Moshe, un visado a Marruecos o una funda de cuero. Todo para ganar dinero. Aunque cuando un policía se acerca para mirar qué está ocurriendo, rápidamente, dos fuertes gitanos le cogen por los brazos y le dirigen velados mensajes de amenaza: «¿Quieres que te haga la manicura, guapo?» o "si quieres te leo el futuro", le disuaden y el policía se aleja raudo de allí. Con sorna, se vuelve a enfatizar la falta de un poder institucional capaz de controlar la sociedad. El agente, intimidado, se retira y deja que sean los gitanos los que suplanten a la autoridad falsificando pasaportes como si aquello fuera lo más normal. Mercado negro de pasaportes, mafias, miseria social y, por supuesto, engaños... esos son los rasgos de la Rusia poscomunista.

${ }^{23}$ De hecho, para los jóvenes rusos una de las profesiones con mayor futuro era convertirse en asesino a sueldo. 


\subsection{Pasado, presente y futuro}

La llegada a París va a significar tanto para Gavrilov como para Andréi el enfrentarse a su propio pasado. Dejan atrás una Rusia venida a menos, tal y como se ha ido desvelando, y se encuentran con aquellos sueños y ambiciones rotos por la Historia. Curiosamente, aquí, se puede encontrar un cierto paralelismo con aquellos hombres y mujeres que huyeron de la Revolución de 1917 y encontraron en la capital francesa su refugio, aunque también tuvieron otros lugares de acogida como Estados Unidos y Lejano Oriente (Pinti, 2017, pp. 195-226). A estos exiliados les encantaba ver representados «ballets de Chaikovski», recoge Figes, en la añoranza de la tierra abandonada (2006, p. 659).Pero frente a estos refugiados aristocráticos, en mayor medida, los nuevos son gentes que huyen de la herencia dejada atrás por la URSS.

La primera escena, a su llegada al aeropuerto, es muy ilustrativa. Jean Paul, el encargado del Châtelet para recibirles, les aguarda para guiarles a su hotel. Pero nada más abrirse las puertas de la zona de equipajes sale un grupo vocinglero y visiblemente borracho, ante la consternación de Jean Paul. Por eso, cuando, en último término, aparece el magnate Tretiakin elegante, del brazo de su bella, rubia y joven esposa, le confunde con Filipov y le entrega un ramo de flores, aunque Gavrilov interviene rápidamente para revelar el equívoco. Claro que este confunde, así mismo, a Jean-Paul con Oliver, su jefe. Y Gavrilov se enfada por no haber sido recibido de forma más oficial. Cuando Jean-Paul pregunta por la orquesta, Gavrilov cambia de tema y le expresa enfadado que están muy cansados de tanto viaje y exige que les lleven inmediatamente al hotel. Y mientras el millonario Tretiakin y su esposa se alojan en un fastuoso hotel, el Bristol, la orquesta es conducida a otro que debió ver tiempos mejores, el Paris Lumiere.

Los integrantes de la orquesta, siguiendo el patrón de antes, bajarán de forma ruidosa, entrando en tromba en recepción, exigiendo, en un caos total, todos a la vez, las llaves de sus respectivas habitaciones. Una vez instalados, los músicos exigen la mitad de los sueldos prometidos. Y cuando Jean Paul les responde que les pagará mañana, el grupo le exige furiosamente que lo haga ya, pues aquel ingenuamente cree que, como han sido invitados a cenar al restaurante Le Trou Normand, no necesitan el dinero. Pero ellos no atienden a razones. Así que Jean Paul tiene que llamar a su jefe para explicarle la situación: «son unos salvajes, quieren lincharme». Oliver le pide que les pague él mismo con su tarjeta. Aunque se resiste, no tiene más remedio que hacerlo. Y cuando Jean Paul se pone a repartirlo, se le abalanzan y atropelladamente, en un desorden absoluto, se lo arrebatan de las manos sin firmar ningún recibo... y salen del hotel. Andréi saldrá corriendo tras ellos, para avisarles que a la mañana siguiente tienen ensayo, aunque no parece que nadie le haya escuchado. Todo ello apunta, no solo a enfatizar más ese aire de comedia, sino un elemento emocional, como el de que los integrantes de la orquesta, por fin, se sienten 
liberados de los agobios y la vida que han dejado atrás con tan pocos alicientes. Es verdad que también se remarca ese estereotipo del carácter impulsivo ruso, visceral y revolucionario, pero por un motivo muy sutil que servirá de marcado contraste en el momento más importante del filme: subrayar su enorme nobleza humana.

Enganchando con estas imágenes, se nos revela otro personaje del que hasta este momento conocemos muy poco, Guylène, la asistente de Anne-Marie, y que se vincula con esa memoria traumática que configura el misterio de las intenciones ocultas de Andréi de contar con Anne-Marie como solista. Cuando Andréi vuelve tras el vano intento de informales de la hora del ensayo, en la recepción le aguarda Guylène. Se conocen. E inmediatamente Guylène quiere saber si ha venido a hablar con ella (Anne-Marie). Pero él lo niega, algo dubitativo. "He venido solamente para el concierto", recalca mintiéndole. Y tras creer en las intenciones de Andréi, se marcha con mucha frialdad.

Se inserta una escena, en flash-back, de una joven Guylène, en un invierno nevado en Moscú, en el que se la ve entrar en la embajada de Francia llevando consigo un estuche de violonchelo. ¿Qué significa todo eso?

Tras el encuentro con Guylène, Sacha acudirá a la habitación de Andréi que se prepara para salir a cenar. Sacha quiere saber si está seguro de tocar la Serenata de Tchaikovski y a Prokófiev ${ }^{24}$, ya que este último nunca ha sido del agrado de Andréi. Sin embargo, él tiene claro que su única intención es tocar a Tchaikovski, el concierto para violín, cerrar ese círculo que tanto le ha marcado su vida. Y mientras conversan, Sacha se fija en una caja que cree que contiene zapatos, se dirige a ella, mientras Andréi pretende infructuosamente que no la abra, pero es tarde. En su interior están recortes de prensa y los CD de Anne-Marie. Eso desvela al espectador que la idea de que ella sea la solista no es casual, pues Sacha cree equívocamente que es porque está enamorado de Anne-Marie. Andréi le hace fijarse en la edad de la joven solista, tiene 29 años: «¿Qué pasó hace 29 años?». Sacha duda, pero luego se le viene a la mente algo ocurrido en esa época. «No me digas que Anne-Marie es... ¿es ella?». «isí!».

Por otra parte, el personaje de Gavrilov se desmarca de los aspectos centrales de la historia, para cumplir sus propias ambiciones ideológicas, queriendo recuperar la herencia comunista que todavía cree que existe. Se acerca solo a Le Trou Normand. Antaño fue un local en donde se reunía con los camaradas del partido comunista francés, situado justo enfrente de su sede. Orgulloso, mira al edificio. Pero al entrar en el local se lleva un chasco, allí no ha ido nadie y todo el interior no es como lo recuerda. En realidad, es un restaurante de comida magrebí. Le recibe el dueño del local, Ahmed, un francés alto y desgarbado con chaleco, de rasgos oscuros. Gavrilov preguntará por los demás comensales, pero no ha aparecido nadie.

${ }^{24}$ Compositor de éxito, con obras como Pedro y el Lobo o, incluso, realizó la banda sonora original del filme Alexandr Névski, de Einsenstein, y afín al Partido Comunista. 
Aunque su mayor interés reside en saber si ha llegado el camarada ${ }^{25}$ Maurice, y se le ve contrariado cuando el otro le indica que no.

Nadie se va a presentar, porque hasta Sacha y Andréi prefieren irse a comer a un McDonald antes que hacerlo con un antiguo KGB. Después de todo, hay rencores que no pasan, a pesar de que les ha servido para organizar el viaje. A Gavrilov le toca cenar solo, entretenido con una bailarina y rodeado de todas las fuentes y la comida encargada para la orquesta. Claro que cuando Ahmed le pasa la cuenta de malos modos, el otro se niega porque le cobra todos los platos ya preparados. Gavrilov se escuda en que no puede pagarle hasta que lo haga el Châtelet, quienes han hecho la reserva. Aunque Ahmed, quien le dice que se apellida Al-Qaeda ${ }^{26}$, no está para bromas y le amenaza si no lo hace.

Al escuchar su implicativo apellido cambia de parecer y paga. Sale de allí con cara de pocos amigos. El guiño es sutil y elocuente, los tiempos han cambiado, se enfatiza que ya nadie tiene respeto por un viejo comunista.

La realidad es que el terrorismo yihadista es lo que, ahora, provoca temor o una reacción precavida. La Guerra Fría ha quedado muy atrás. Aunque su actitud cambia cuando se encuentra con su antiguo y viejo camarada Momo, Maurice. Entonces es cuando se aclara ese interés de Gavrilov por el antiguo restaurante; era su "antiguo cuartel general». Pero Momo le explica que lo tuvieron que vender ante el descenso de afiliados. "Pronto venderemos hasta la sede. Hay más despachos que miembros, pronto no podremos ni pagar la limpieza», concluye funesto Momo. Mientras caminan, al otro lado de la calle, Ahmed retira la tela en la que se podía leer Le Trou Normand, y deja al descubierto el verdadero nombre actual: «Chez Sidi Mortar».

Todo ello demuestra ese proceso de decadencia del peso de la izquierda comunista en la sociedad europea. No solo, en la alusión, hemos visto un comunismo ya extinto en Rusia, sino en la vieja Europa. Un proceso de cambio que, con humor negro, expresa que ha pasado de tener su epicentro en la confrontación ideológica entre el modelo occidental y soviético, a otras problemáticas como el terrorismo global. No ahonda en ello, ni se pretende, solo es el sutil reflejo de cómo el cine también recoge aspectos significativos del contexto del rodaje, y el modo en el que el humor desvela realidades nuevas.

Los dos viejos comunistas acaban en una cafetería francesa. Gavrilov, grave, le expresa a Momo sus ocultas intenciones, de ahí su regreso, y muy seriamente le dice: «Momo, hay que cambiar esto, hay que volver a poner al partido en cabeza de

${ }^{25}$ El término no es baladí ya que encarna ese lenguaje internacionalista e igualitarista comunista que, tras el fin de la URSS, comenzó a perder ya su fuerza.

${ }^{26}$ Nombre de la organización creada por Bin-Laden para impulsar la yihad, y cuyo éxito más funestamente notorio fue el atentado del 11-S contra las Torres Gemelas de Nueva York. 
Francia, del mundo, dar ejemplo». Y extrae de su cartera la carpeta de su despacho. "¿Estás listo?». Gavrilov todavía tiene ese utópico sueño de impulsar la revolución.

Más adelante, veremos a Gavrilov en la amplia sala de conferencias de la senda del Partido Comunista con Momo. Pretende reunir a miles de simpatizantes (aunque Momo le indica que ya solo quedan 1000 afiliados), encender la chispa del movimiento proletario, como antiguamente, con miles de simpatizantes atraídos por el mensaje socialista. Gavrilov ha traído consigo la bandera estandarte del Congreso del Partido en Moscú, de 1966, como un recordatorio de las glorias pasadas. Y recuerda que lograron el 100 \% de los votos: «Un pueblo unido por la misma causa». Momo le responde que no es posible olvidar algo así, ya que no se puede superar esa cifra. Pero todo es un mero espejismo, nada más, el ensueño de dos viejos que se han quedado anclados en su propio pasado, sin asumir la realidad vigente.

Paralelamente, Andréi, radiante, observa desde el escenario principal del Châtelet, contemplando con orgullo el patio de butacas y los palcos. Por fin, ha logrado parte de su sueño. Pero los únicos que han llegado son él, Sacha y el multimillonario Tretiakin. Oliver, el director, acompañado de sus ayudantes se acerca exultante para saludarle y decirle que en muy pocas horas se han vendido todas las entradas. Andréi le agradecerá la posibilidad de tocar allí. Entretanto, el pobre Jean-Paul pide a Oliver que le devuelva el dinero que tuvo que adelantar para pagar la cena de la orquesta en un restaurante ruso. Y le indica que allí comieron poco y bebieron mucho. Subrayando ese estereotipo de los rusos como grandes bebedores. $E$, irónicamente, aunque la culpa no es de Jean-Paul, le reconviene: «Si usted los salvó ¿dónde están? ¿Oye usted música, es un Tchaikovski inédito, Silencio para violín y orquesta?». Y el mismo Oliver se acerca enfadado a Andréi, indicándole que solo haya cuatro miembros de su orquesta presentes. Justo Gavrilov aparece, en ese instante, para justificar que lleguen tarde, apelando a que son rusos y eso es parte de su «cortesía».

Claro que, en realidad, en esta gran farsa, los integrantes de su orquesta han venido a París empujados por las perspectivas de ganarse un sustento. Viktor y su hijo Moshe están intentando vender caviar que han traído de Rusia. Pero son otros tiempos y su hijo le indica que está desfasado, que si hubiesen traído móviles chinos los habrían vendido en una hora. Aunque el padre le replica que un «judío ruso vendiendo móviles chinos» es pecado. Pero Viktor no consigue ningún trato por su caviar, que lo hay en abundancia en Francia y más barato. Así que cuando salen de otro restaurante, le reprocha a su hijo que si es tan listo por qué no ha traído los dichosos móviles chinos. Y el otro le responde que ya lo ha hecho, repartiendo 50 entre los integrantes de la orquesta (con tarjetas SIM falsas), menos a Andréi, a Sacha e Iván, para que no lo sepan. Al enterarse, a Viktor se le cambia la cara y le expresa su orgullo por parecerse a él en materia de negocios. Si bien, tiene un grave problema: nadie los quiere devolver. Así que Viktor, enojado, decide llamarles. Pero todos ellos optan por no contestar. Se nos muestra dedicándose a los mismos negocios 
que han dejado atrás en Moscú. Es como si todo ellos, a pesar de que están en Francia, llevasen consigo las actitudes y las estrategias de supervivencia utilizadas en Rusia. El mismo Viktor simboliza a esos vendedores ambulantes de aquellos años 90 , en los que el mercado negro era tan importante, esencial y lucrativo (Service, 2000, p. 478); y al mismo tiempo el director vuelve a ironizar, con su marcada exageración, con los estereotipos (los judíos, en esta ocasión, como hábiles comerciantes).

En el Châtelet, aparecerán finalmente, Anne-Marie seguida de Guylène por el acceso principal del teatro. Andréi y Anne-Marie se miran sin saber muy bien qué decirse, ambos sienten admiración mutua. El momento mágico se ve roto por la entrada ruidosa y repentina de un equipo de televisión, que aparta sin recato a Anne-Marie. Tretiakin les manda colocarse junto a las otras cámaras que ha desplegado la televisión francesa. Oliver se queda desconcertado, porque no sabe lo que ocurre y llama a Jean-Paul, su ayudante, para que aclare el asunto. Sin embargo, Anne-Marie comienza a ponerse nerviosa por la ausencia de los músicos. Lo peor de todo resulta cuando Tretiakin decide mostrar sus habilidades con el violonchelo y eso hace que todos se giren hacia él al escuchar el horrible sonido que provocan sus notas. Sacha reaccionará de forma oportuna, y empezará a tocar una melodía con un candor y una dulzura tales que lleva a que Tretiakin deje de tocar, y a que Anne-Marie, maravillada por el sonido, se calme.

Cuando se interrumpe, ella le pide que continúe, porque es precioso lo que está tocando. Pero el otro de forma humilde le indica que no es el mejor de los que hay en la orquesta, que necesita ensayar mucho frente a los demás, que no lo requieren por su destreza. Es una manera de justificar, así, la ausencia de los otros. Andréi no puede más que secundar tal explicación. $Y$ afirmar que su idea es que no haya ensayos porque eso «mata la espontaneidad». E insiste en que para él «la música es espontaneidad».

Aunque ella no está tan convencida: «¿Quiere decir que la técnica del Bolshói es tan perfecta que...?». Pero Andréi le aclara que no se trata de ser "pretencioso», que para él no es técnica sino «ialma!» iespíritu!». Y justifica que los integrantes de la orquesta no hayan aparecido porque están inspirándose en la Ciudad de la Luz... Y cuando parece que ha convencido del todo a Anne-Marie, aparece Vasili con toda su familia gitana. Entran configurando un caos monumental, con la ropa y los instrumentos que se había comprometido a conseguirles. Los van colocando en sus sitios, con desorden y con algarabía, mientras Vasili le explica que no ha podido conseguir un fagot por culpa de la policía que se mete en todo. Algunas gitanas, incluso, se ponen a planchar allí mismo la ropa que han traído. Andréi se fija en el aire consternado de Anne-Marie. Y que, después de todo lo que le ha dicho Andréi sobre la espontaneidad y el alma de la música, todo parece falso, nada profesional. Sin embargo, cuando Anne-Marie quiere llamar a Oliver, Vasili coge un violín y se pone a tocar alrededor de Anne-Marie, otros dan palmas, pero tras estos acordes para llamar su atención, muestra su virtuosismo con el violín, lo cual lleva a que la 
solista cambie la expresión de su semblante, entre admirada por lo que ha escuchado y sorprendida. Y quiere saber cómo ha logrado tanto virtuosismo.

La música, en ambos momentos, cuando toca Sacha y, luego, Vasili, se convierte en una gran metáfora de equilibrio y belleza, en un mundo caótico y desordenado en el que cabe identificar la ausencia de los integrantes de la orquesta, o la llegada de la familia gitana, con la nueva Rusia (Pomerantsev, 2017).

La aparición de la televisión rusa, que no gusta a los representantes del Châtelet, pues tienen un contrato de exclusividad con France Télévisión, también es reveladora, en su valor simbólico, de las malas relaciones entre Europa y Rusia.

Oliver y sus representantes se reúnen en el despacho con Tretiakin para intentar convencerle de que retire sus cámaras. Sin embargo, para sorpresa de Oliver se encuentra con que ya ha vendido los derechos de retrasmisión para toda Rusia y que el mismo presidente ruso va a verle vía satélite. $\mathrm{Y}$, entonces, les advierte: "¿Quiere que le cortemos el gas a Europa Occidental?». Claro que ni el abogado ni Oliver quieren eso. Así que este se las ingenia para aludir a una cláusula del contrato en el que no son responsables de lo que ocurra si se producen «desastres naturales»... o lo que es lo mismo, que la señal de retrasmisión se pierda en el espacio, en otros países... "eso es un desastre natural». No puede hacer mucho más, aunque sea un burdo intento de complacer a Tretiakin, que saben que tiene la sartén por el mango a este respecto.

El director del Châtelet no tiene más remedio que aceptar que la televisión rusa se encargue también del concierto, ante el compromiso de ver retirada a la orquesta.

La amenaza del multimillonario, en este hábil humor negro, deja entrever las connivencias entre el poder político y empresarial en Rusia, lo que Taibo denomina «política subterránea» (Taibo, 2017, p. 24). En otras palabras, refleja la influencia de esta nueva oligarquía, representante del complejo industrial-financiero, que marca las reglas de juego políticas dependiendo de sus intereses y que abarca verdaderos emporios no solo industriales, sino financieros y de control de los medios de comunicación (Service, 2005, p. 346). Y, al mismo tiempo, ironiza sobre un hecho real, la dependencia que tiene Europa del gas ruso (representa nada menos que el $40 \%$ de las importaciones), amén de otros recursos (Taibo, 2017, 40-42). De hecho, puede que el comentario viniese inspirado en la noticia de que, en enero de 2009, Rusia cortó el gas a toda Europa para presionarla a subir los precios e impulsar un gaseoducto nuevo (Bonet, 2009).

Pero, subrepticiamente, nos muestra unos ciertos rasgos o clichés, como que los rusos son, despiadados, meros chantajistas, que presionan a otros países para alcanzar sus intereses políticos (como ha hecho el multimillonario) o ya, como en este caso, musicales. Igual que en otras secuencias se dejaba en mal lugar a los poderes institucionales rusos, mayormente subordinados a las mafias (escena de la boda) o todavía a un carácter autocrático, como es la situación del pobre Andréi 
en el Bolshói de conserje, que nos desvela una caracterización negativa, vinculada a una cierta imagen rusofóbica sostenida desde Occidente. Pero es verdad que el filme no se queda ahí. También nos va a hablar del alma musical eslava, del otro yo de los rusos, encarnado en Andréi y Sacha.

Y aunque hay una mirada muy crítica, en la decepción que ha provocado este proceso de trasformación de la sociedad comunista a otra capitalista, también refleja como "los rusos quieren una sociedad diferente de aquella en la que han vivido» y de ahí que se sientan atraídos por la influencia Occidental, aunque no dejan de respetar ni de valorar las tradiciones rusas. Y, como incide Service, a pesar de todo, es un país "que no carece de esperanza e iniciativa (...) Existe vitalidad en la Rusia del pueblo» (Service, 2005, p. 393). Aspecto que, sin duda, queda claro con el plan urdido por Andréi.

\subsection{Música, persecución judía y la última armonía}

La música como fundamento de la espiritualidad y las pasiones humanas más nobles, la pugna contra el antisemitismo (o aquellos valores de persecución contra las minorías) y la memoria liberadora (frente a los totalitarismos y su pretendido olvido) se van a convertir en los ejes fundamentales de esta última parte de la película.

La situación para Andréi y Sacha, como se ha comprobado, no puede ser más desesperada. Todo parece perdido. La mayor parte de su orquesta se halla desperdigada por París. Sus verdaderas intenciones no eran tocar, sino aprovecharse de esta circunstancia para ganar dinero: ante la necesidad virtud. La prueba es que no han asistido al ensayo y no saben ni tan siquiera cómo van a lograr ponerse en contacto con ellos. Tanto es así que Andréi, con un funesto presagio, entiende que no lo van a conseguir, incluso, encuentran a algunos tocando en el metro de París. De nuevo, todo parece abocado al fracaso, a la imposibilidad de cerrar este círculo vital. Incluso, a eso se une que en la recepción del hotel les aguarda Oliver, furioso, que le advierte a Andréi que si no aparecen dos horas antes del concierto lo cancela todo. Aunque la realidad es que Oliver está comprometido de lleno con el concierto, y si lo suspende, él mismo puede ver peligrar su trabajo porque «nunca hemos vendido tanto». Ingenuo, cree que eso es parte del carácter ruso, son como «mulos», despotrica, que hay que darles un golpecito para que reaccionen. Volviendo a enfatizar ese estereotipo de los rusos como personajes de vida desordenada y que solo responden al despotismo.

Como se vislumbra, el ritmo y la tensión no cesan, Mihaileanu maneja con agilidad e inteligencia la compleja construcción visual.

Así, la cena entre la brillante violonchelista Anne-Marie y el maestro Andréi, en un bonito restaurante parisino, trascurre por unos derroteros inesperados, que desvelan parte de las claves de la historia, aunque sin saber que todo el trauma vivido 
y sufrido por Andréi se refiere a sus padres y a la repercusión que tuvo el concierto en ella. Y aunque Anne-Marie siente auténtica devoción por el maestro, al que ve un hombre consumido por la obsesión hacia el pasado y la tristeza, se despedirá de él un tanto decepcionada por esperar de ella algo que todavía no entiende.

Durante la cena, un tanto bebido, Andréi le desvela a Anne-Marie su obsesión por el Concierto de Tchaikovski, al creer que en este encontraría la «última armonía, el absoluto musical, la perfección». Y menciona a una tal «Lea Strum, brillante, extraordinaria», junto a su marido Yitzhak. Hasta que, un día, le dijeron que Brezhnev quería echar a los músicos judíos de la orquesta. Entonces, confiesa que le entró pánico, porque Lea era judía. A pesar de todo, decidieron seguir y tocar el Concierto. Aunque confiesa que actuó así no solo para defender a los judíos, sino que lo hizo por puro egoísmo, por «un sueño loco». Necesitaba «tanto a Lea como a los judíos, para lograr la armonía». Proseguirá. «12 de junio de 1980. Concierto». Y describe el marco: «Teatro Bolshói. La sala llena. Muchísima gente. Periodistas del mundo entero. Managers, colegas. Concierto. Empezamos. El milagro llegó. Lea, sublime. Su violín mágico me llevó a mí y a la orquesta hacia el cielo, muy alto. Todos volamos, nosotros junto al público, volamos hacia la última armonía...». Y acaba el embrujo de recordar el pasado, de sentir la música a su alrededor. «... Pero el concierto se paró a la mitad, no pudimos llegar a la última armonía. Brezhnev detuvo el concierto a la mitad para humillarnos ante el público. Brezhnev nos cortó las alas. Caímos desde muy alto. Después echaron a todos los judíos. Lea, Sacha, a todos...». Y, por supuesto, a él.

Anne-Marie se interesará por la suerte de Lea, por la que se siente fascinada. Y Andréi le explicará que ella y su marido cayeron en el error de conceder una entrevista en Radio Free Europa, radio americana prohibida en la URSS. «Ellos... criticaron a Brezhnev ¿sabe?». Y, por supuesto, esas palabras ya desvelan que fueron detenidos y represaliados. Este instante nos sitúa en aquella sociedad soviética tan rígida y controladora en la que la disidencia era perseguida con dureza, a pesar de los nuevos tiempos abiertos por Jruschov, tras el estalinismo.

No fue, en todo caso, una disidencia anticomunista sino para «defender los de-

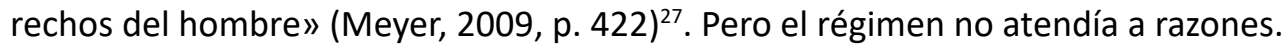

Cuando Sacha recoge a Andréi en el restaurante encontrará a un hombre derrotado ante la negativa de Anne-Marie de tocar. «jBravo Brezhnev! Has vuelto a vencer», exclamará el infeliz de Sacha. La autocompasión aflige a Andréi, ante el peso de una memoria que no es capaz de superar. Sin embargo, el filme aboga porque sí es posible hacerlo. Podemos encontrarnos con el pasado en el presente y,

${ }^{27}$ La lista de disidentes fue larga, aunque nunca tuvieron un programa político definido, solo eran críticos contra los abusos del sistema, intelectuales contestarios o personas comprometidas que criticaban la agresiva política exterior soviética. Y eso que había firmado los acuerdos de Helsinki, 3 de julio de 1973, en defensa y garantía de los derechos humanos fundamentales. 
ahí, la música se va a convertir en un influjo catártico para todos ellos, para Andréi, Anne-Marie, Guylène e, incluso, los músicos de la misma orquesta, que recuperarán su valor y autoestima.

Sacha adquiere un activo papel en este instante. Muestra cómo los individuos solos nos conseguimos nada, pero que la amistad y el compromiso puede hacer mucho por las personas. Por eso, acudirá desesperado a donde Anne-Marie para convencerla de que participe, lanzándole una pregunta al aire que acabará por derribar el último muro negativo de Anne-Marie: «¿Y si al final del concierto encontrara a sus padres?». Pero las palabras de Sacha no son nada casuales, sino muy singulares e icónicas. Desvelan muy bien la imposibilidad de un olvido total y absoluto (Martínez Rodríguez, 2011, p. 90) y como la memoria emergente puede ayudar a redimir la culpa y liberar ciertos traumas. La misma Guylène, que ha pretendido mantener a Anne-Marie lejos de ese pasado, al final, se da cuenta de que necesita encontrarse con él. Le instará, en una carta a modo de despedida, a hacerlo, y le pedirá perdón por haberle mentido todos estos años. Le ha dejado, simbólicamente, la partitura de Lea, con sus anotaciones.

$\mathrm{Y}$, al fin, encaja todo. Los integrantes de la orquesta diseminados por París reciben un inesperado mensaje, "vuelve, por Lea»... El pasado llama a sus puertas. Pero, cuando todo parece ordenarse, Mihaileanu pone, de nuevo, en suspenso la historia.

El verdadero director del Bolshói, Leonid Dimitrievich, de vacaciones en París con su familia, se lleva una gran sorpresa cuando ve en un cartel el anuncio de una única actuación del Bolshói en la ciudad parisina y, por supuesto, se queda perplejo e irá a impedir que nadie actúe en su nombre. Mientras, las repercusiones del concierto han sido enormes, asistiendo lo más granado de la sociedad parisina, representantes del gobierno, empresarios, con los que habla el millonario ruso.

Además, antes de dar comienzo, se produce un interesante alegato, cuando Andréi convence a Gavrilov de que no se vaya, pues su intención es acudir a la sede del Partido Comunista, donde le aguarda Momo, para relanzar el comunismo. Andréi le recriminará que, a estas alturas, eso es «ridículo» y muy alterado le dice: «no has hecho bastante discurso de mierda en Moscú». Pero el otro le replica: «He venido hasta aquí para construir un sueño, un sueño aún mayor si cabe, puedes comprender estas palabras, el gran sueño». Y Andréi le responde: «Sí, sí, lo recuerdo. Proletarios del mundo uníos los unos contra los otros». Y Gravilov le censura que solo piense en su concierto. Es verdad, pero el motivo de Andréi es más universal, y le expresa: «Una orquesta es un mundo, Iván, un mundo, Iván, cada músico llega con un instrumento y un talento diferente, y se reúnen durante el tiempo de un concierto para tocar juntos con la esperanza de producir un sonido mágico, de hallar la armonía. Eso es el auténtico comunismo. Durante el tiempo de un concierto». A pesar de las hermosas palabras, Iván se marcha para cumplir con lo que considera que es su misión, dejando en la estacada a Andréi. 
Claro que la convocatoria de comunistas en la sede del partido ha reunido a un puñado de ellos, quedando la mayoría de los bancos libres. Momo, en el atril principal, les anuncia que, por fin, Moscú ha vuelto para apoyarles en la figura de Iván y lo presenta como un «jauténtico líder ruso!». Pero es un cuadro totalmente desangelado, e ilustra bien cómo ya no existe ese espíritu revolucionario al que se aferran Momo e Iván.

Justo cuando Gavrilov alcanza la calle para coger un taxi para dirigirse a la sede del Partido comunista, de otro se baja Leonid Dimitrievich muy enfadado. Capta su intención. Entonces, Iván ha tomado otra decisión para redimirse. Y haciéndose pasar por mera víctima le coge del brazo para guiarle dentro del teatro, para encerrarlo y no pueda boicotear la actuación. Esta decisión de Gavrilov puede contener una segunda lectura, aparte de ser un mecanismo para acentuar aún más el enredo y la comedia. Puesto que él, como todos los demás, ha venido a París empujado por sus motivaciones personales: reconstruir la internacional comunista. Pero, al final, claudica por algo que considera que es mucho más importante: el concierto. Un concierto que encarna no solo la voluntad de Andréi de pagar su deuda con el pasado, sino de dejar que la música hable en un lenguaje emocional y humanista que va más allá de los tiempos y las personas, unido, en cierto modo, a unos valores universales de armonía y entendimiento. La propia composición multirracial y étnica de los integrantes del elenco actoral del filme se halla compuesta por rusos, gitanos, judíos, etc., incluido el público francés que, según el director, le imprime un sello único, pues su intención es constituir un "diálogo cultural», en el que «el concierto expresa esa armonía que nace del choque de culturas» ${ }^{28}$.

En el interior, la orquesta se prepara. Tretiakin imparte órdenes a los operadores de la cabina de televisión de cómo han de ir enfocadas las cámaras (dirigidas a él, por descontado). En su casa, han organizado todo un convite para amigos y conocidos, con el fin de verle tocar en directo, en una gran pantalla puesta allí para la ocasión. Su madre está muy orgullosa recibiendo a los asistentes. Este dirigismo exagerado e histriónico del millonario exigiendo la máxima atención hacia su persona, y no a la orquesta, es muy revelador, alusión del asfixiante control que se tiene sobre los medios de comunicación públicos (todos favorables al Kremlin, por supuesto) (Gessen, 2018a, p. 257).

En el teatro, al público se le observa perplejo porque el modo de afinar los instrumentos suena mal, descompasado. Por un lado, previo al clímax final, se crea esta especie de anticlímax. Tras tanta improvisación y el caos organizativo no puede salir nada bueno. Salen Anne-Marie y Andréi a escena. Es la hora de la verdad. Andréi cruza la mirada con Sacha quien bajando la cabeza parece confirmarle que, por fin, están allí y lo han conseguido. Pero cuando echa un vistazo a su orquesta,

$28<$ https://www.lahiguera.net/cinemania/pelicula/5058/comentario.php> [consultado el 28/04/2018]. 
Andréi se da cuenta de que faltan Víktor y su hijo. Y justo cuando no tiene más remedio que empezar, aparecen, provocando cierta hilaridad entre el público. Andréi, consternado, se prepara, porta la misma batuta de aquel concierto, arreglada con una cinta, cierra los ojos y agita sus manos... pero los primeros acordes comienzan a fallar. El público lo nota y un crítico de música, Laudeyrac, que odia a Tchaikovski (y que Oliver le ha presentado a Andréi antes de la función), sentado en la sala de butacas, se regodea con los fallos. Hasta Oliver se tapa la cara, percibiendo cómo la función está abocada al fracaso. Gavrilov, tras encerrar a Leonid, pide que si Dios existe, obre un milagro para que les ayude a salir bien de esto.

De pronto, todo cambia cuando interviene Anne-Marie, sus acordes con el violín provocan una honda emoción. Los mismos integrantes de la orquesta parecen, de pronto, dejarse envolver por el sonido del violín y, entonces, se obra el milagro, la orquesta responde, el público se deja seducir por la música y Oliver llora, hasta el mismo Gavrilov tiene que decir: «¡Dios mío! No me lo puedo creer, i ¿existes?!» (en referencia a Dios).

Los planos se suceden y la orquesta alcanza su clímax, la última armonía... que es cuando Anne-Marie descubre la verdad de su pasado... y empujados por la magia de la música, en off, escuchamos a Andréi acabando de contarle la verdadera historia de sus padres sin ambages y la suerte que corrieron. Como Guylène la salvó transportándola en una funda de violonchelo. Todo eso desvela a Anne-Marie su tragedia familiar y quién es. Y Andréi continúa mientras tocan revelando el amargo destino de Lea, que murió de debilidad y de frío, en 1981, en Siberia, imaginándose esgrimiendo un violín ofreciendo el concierto de Tchaikovski y cómo su marido moriría seis meses después de pena.

Las imágenes del pasado se superponen al presente. Y Andréi se arroga la culpa de todo lo ocurrido y le confiesa que Lea era su madre. Anne-Marie sigue tañendo el violín y, al mismo tiempo, cerrando este círculo que inició su madre con su pasión por Tchaikovski. Andréi le pide perdón, algo que ella se lo concede afirmando con la cabeza.

Esta larga secuencia tan lírica lleva a que también Andréi se libere del dolor y la carga.... Así lo expresa tan sintéticamente Martínez Rodríguez: «La memoria es, al mismo tiempo, conocimiento y sentimiento" (2011, p. 47). Lo cual encaja como un guante con la fuerza que el cine nos trasmite, conocemos la historia y la sentimos.

Todos los demás implicados atraviesan el mismo proceso emocional de liberación y melancolía. Vemos a Irina, la mujer de Andréi, en su piso de Moscú, con lágrimas en los ojos, mientras escucha el concierto por la radio. También Guylène, que ha ido al teatro, llora liberada, al fondo, oculta en el patio de butacas. Y, en ese toque de humor, también se muestra en un plano a Tretiakin amordazado y atado para que no arruine el concierto, algo que provoca el estupor de su madre, cuando lo ve por televisión. Al mismo tiempo, los hijos y la mujer de Sacha, que viven en Israel, descubren a su padre en la televisión y le observan con orgullo. Oliver y Jean- 
Paul, entre bastidores, se besarán empujados por el embrujo que les ha envuelto el concierto de Tchaikovski, un guiño al hecho de que este también era homosexual (Gessen, 2018a, p. 215). Un modo sutil de criticar, así mismo, la creciente cultura homófoba existente en Rusia (Service, 2005, pp. 366-367) o las posturas actuales más intransigentes de Putin contra los gays (Taibo, 2017, p. 55).

Nuevas imágenes se superponen, anticipando un futuro prometedor a la orquesta, un éxito clamoroso que les lleva a ofrecer más funciones y una gran repercusión en todos los periódicos del mundo, giras hasta Japón, CD, en los que tanto Andréi y Anne-Marie como el resto de acompañantes conforman un tándem magistral. Se burlarán de Leonid, en un aeropuerto, cuando se cruzan con él y el Bolshói. Así, Andréi viste como si fuese una estrella del rock. Aunque, en su tono exagerado, no sabemos si este anticipado devenir va a ocurrir o no de verdad, lo deja a la elección del propio espectador, pues tras estas imágenes se nos retrotrae al final del concierto. Cuando acaban, el público reacciona con una cerrada ovación y levantándose de sus asientos. Le sigue a ello las miradas radiantes que comparten todos los propios integrantes de la orquesta que denotan un orgullo identitario ruso, más allá de los nacionalismos o ideologías, gestado en su riqueza y bella cultura musical. Anne-Marie no puede contener su agitación y rompe a llorar. Se funde en un abrazo con Andréi, mientras el público les lanza rosas y los propios músicos golpean con sus instrumentos mostrando agradecidos la potencia e intensidad de ese instante, cerrando así una compleja escena ${ }^{29}$.

Memoria, persecución, traumas e historia se sintetizan en este soberbio cierre. Porque, ciertamente, aunque entre los años 30 y los 50 la persecución que se hizo de la disidencia, real o imaginada, fue espantosa, no acabó con la muerte de Stalin. Los famosos Gulag y los campos de trabajo de Siberia configuran parte del imaginario que describe la Rusia del dictador georgiano (Applebaum, 2004). De hecho, solo tras 1965, «el terror de masas» (Taibo, 2000, p. 17) había desaparecido. Pero eso no quiere decir que no hubiese un vigilante y controlador aparato de seguridad que exiliaba a los intelectuales o escritores críticos con el régimen, y que mandaba a muchos de ellos a Siberia. Aunque sus condiciones de vida no eran tan draconianas como en el periodo anterior, no dejaban de ser duras (Meyer, 2009, p. 423) ${ }^{30}$. Pero es verdad que esa imagen se quedó grabada en Occidente, y tras Stalin, todavía se creía que "las represalias seguían siendo tan importantes como en el pasado»

29 <https://www.lahiguera.net/cinemania/pelicula/5058/comentario.php> [consultado el 28/04/2018]. El mismo director cuenta cómo rodar esta escena fue una pesadilla para él preparándola plano a plano.

${ }^{30}$ Así, Andréi Amalrik, fundador del Comité de los Derechos del Hombre de Moscú, fue condenado a tres años en un campo especial; en 1974, Solzhenitsyn fue expulsado de la URSS, tras su publicación fuera de la URSS de Archipiélago Gulag; también se persiguió a Andréi Sajarov, padre de la bomba atómica soviética, y a otros científicos y escritores muy críticos con la situación de vida en la URSS. 
(Lewin, 2006, p. 232). Aquí el director juega con el imaginario social. Y le sirve para homenajear, de forma hábil y acertada, a aquellos grupos disidentes perseguidos por el régimen soviético, tan solo por reclamar más libertad o poder pensar de un modo diferente (Lewin, 2006, pp. 204-211 y Greene, 2011, p. 85). Porque, después de todo, «lo más relevante de las experiencias del trauma y la culpa», como tan bien se ilustran en el filme, "es que no se limitan a trasladarnos un simple conocimiento, un contenido intelectual, sino que nos hacen llegar una determinada sensibilidad, una forma de percibir una realidad» (Martínez Rodríguez, 2011, pp. 49-50).

\section{CONCLUSIONES}

La inverosímil trama de El Concierto, llena de casualidades y despropósitos, exageraciones y momentos forzados para provocar hilaridad, no impide apreciar que el filme contiene buenas dosis de realidades encubiertas. La gran virtud del filme de Mihaileanu radica en su estilo desenfadado y honesto de contar experiencias humanas descarnadas con un tono dulce y esperanzador. Un acercamiento en el que la admiración por la belleza de la música y el arte ruso se entremezcla con una visión irónica y ácida de las secuelas del fin del régimen comunista en Rusia (y la utopía socialista en Europa), pero que también nos habla, después de todo, de los traumas heredados del pasado.

Los equilibrios tanto estilísticos como argumentales, de farsa y comedia al mismo tiempo, que realiza, con una representación un tanto caricaturizada y estereotipada de la sociedad rusa frente a la gravedad de la realidad cotidiana, permiten que el juego del plano y del contraplano resulte sumamente representativo de una realidad confusa e inestable, evocando, desde un desenfadado y marcado humor, la capacidad de adaptación humana, en las peores circunstancias, y el encuentro con la verdad y sus dramas.

La aparente simplicidad de algunos recursos argumentales (como que todos los músicos responden al mensaje de móvil para acudir al concierto), el uso de algunos clichés y estereotipos (como los brutos mafiosos rusos, una nueva clase de ricos vulgares y pagados de sí mismo y sin gusto artístico), o el viejo comunista aferrado al ideal perdido, se conjugan de una manera hábil y eficaz, que redunda no tanto en querer radiografiar con puntillosa veracidad la Rusia post-comunista, como en desnudar, con un agudo y pícaro sentido de la comedia y la farsa, los excesos de una sociedad que pasó de ser el ideal comunista al paraíso capitalista. El lírico enfoque, además, sirve de contraste con un marcado nacionalismo ruso que idealiza en exceso, o bien ignora ciertos capítulos de su historia que se están dando en la sociedad rusa actual, con unos elevados grados de xenofobia, homofobia y autoritarismo.

El filme trata de expresarnos que todas las sociedades tienen sus propias tragedias y que el arte y la verdad pueden ayudar a liberarnos como individuos, a 
enfrentarnos a ellas desde el sentimiento. Mihaileanu convierte El Concierto en inteligente, hábil y sutil homenaje a todos aquellos que sufrieron persecución, ya no solo en la época comunista, sino incluso, a nivel universal. Y, con todo, utiliza a la música, de forma ágil y brillante, como un símbolo muy recurrente de encuentro y transgresión, de liberación, después de todo, de la rabia, frustración y dolor que hay ocultos tras ese velo de ignominia y de olvido dejado atrás por la arbitrariedad y la caprichosa voluntad de las dictaduras. En donde, entre muchas otras cuestiones, estaba proscrito el humor, el reírse de la autoridad y, por supuesto, de poner en duda ese obtuso y mayormente falso sentido de la realidad que pretendía imponer. El cine, como todo buen instrumento de análisis de la sociedad, nos muestra claramente aquí cómo se puede plantear una visión crítica de la historia y del presente (un contraanálisis) mediante un dibujo muy humano de los padecimientos y sufrimientos de personas normales y corrientes. Convirtiéndose, así, El Concierto en un proverbial y muy inteligente alegato humanista de liberación emocional sobre el pasado (en concreto, sobre la represión soviética) y la necesidad que tenemos de liberarnos de sus traumas para seguir encarando con garantías el presente. <

\section{REFERENCIAS BIBLIOGRÁFICAS}

<https://www.filmaffinity.com/es/film154052.html>. [Consultado el 21/11/2018].

<http://cineuropa.org/ff.aspx?t=ffocusarticle\&l=es\&did=51225\&tid=922>. [Consultado el 28/04/2018].

<https://www.lahiguera.net/cinemania/pelicula/5058/comentario.php>. [Consultado el 28/04/2018].

<https://www.vertigofilms.es/pressbooks/elconcierto.pdf>. [Consultado el 28/04/2018].

<https://www.imdb.com/title/tt1320082/awards?ref_=tt_awd>. [Consultado el 01/03/2019].

Applebaum, A. (2004). Gulag: historia de los campos de concentración soviéticos. Madrid: Debate.

Bayón, F. (1983, 17 de marzo). Los judíos en la URSS, una minoría perseguida. El País <https://elpais.com/diario/1983/03/17/internacional/416703605_850215. html>. 
Bolufer, M., Gomis, J., y Hernández, T. M. (eds.). (2015). Historia y cine. La construcción del pasado a través de la ficción. Zaragoza: Institución Fernando El Católico.

Burke, P. (2001). Visto y no visto. El uso de la imagen como documento histórico. Barcelona: Crítica.

Burrin, P. (2004). Francia bajo la ocupación nazi, 1940-1944. Barcelona: Paidós.

Carrère d'Encausse, H. (2001). Rusia inacabada. Barcelona: Salvat Contemporánea.

Claudín, C. (2011). ¿Qué Rusia, veinte años después? Revista CIDOB d'afers internacionals, 96, pp. 11-23.

Cuéllar, J. M. (2010, 12 de marzo). Tchaikovski como el más bello reto. $A B C<$ https:// www.abc.es/20100312/cultura-cine/tchaikosvky-como-bello-reto-20100312. html>.

Fentress, J. y Wickham, C. (2003). Memoria social. Madrid: Frónesis.

Fernández, R. (2003, 3 de julio). Un magnate ruso compra el Chelsea. El País.

Ferro, M. (1995). Historia contemporánea y cine. Barcelona: Ariel.

Figes, O. (2006). El baile de Natacha. Una historia cultural rusa. Barcelona: Edhasa.

French, Ph. (2010, 18 de julio). El Concert. The Guardian <https://www.theguardian. com/film/2010/jul/18/the-concert-film-review>.

Gessen, M. (2018a). El futuro es Historia. Rusia y el regreso del totalitarismo. Madrid: Turner.

Gessen, M. (2018b). El hombre sin rostro: el sorprendente ascenso de Vladimir Putin. Barcelona: Debate.

Greene, S. A. (2011). La sociedad civil rusa, veinte años después. Revista CIDOB d'afers internacionals, 96, pp. 81-96.

Halbwachs, M. (2004). La memoria colectiva. Zaragoza: Prensas Universitarias de Zaragoza. 
Hoffman, D. E. (2003). Los oligarcas: poder y dinero en la nueva Rusia. Barcelona: Mondadori.

Holden, S. (2010, 29 de julio). Getting the Old Band Back Together. New York Times.

Hueso Montón, A. L. y Camarero Gómez, G. (coords.). (2014). Hacer historia con imágenes. Madrid: Síntesis.

Lee Myers, S. (2018). El nuevo zar. Ascenso y reinado de Vladimir Putin. Barcelona: Península.

Lewin, M. (2006). El siglo soviético. Barcelona: Crítica.

Masurel, C. (2009, 20 de noviembre). Le Concerte. Artistik Rezo <https://www. artistikrezo.com/cinema/l-le-concert-r-de-radu-mihaileanu.html>.

Martínez Rodríguez, A. (2011). La paz y la memoria. Madrid: Catarata.

Matías López, L. (2002). La huella roja. Historias de la Rusia postsoviética en el cambio de milenio. Barcelona: Península.

Meyer, J. (2009). Rusia y sus imperios (1894-2005). Barcelona: Círculo de Lectores.

Ocaña, J. (2010, 10 de marzo). Carcajadas políticas El País <https://elpais.com/ diario/2010/03/12/cine/1268348414_850215.html>.

Pinti, A. (2017). Revolución rusa y primera oleada migratoria (1997-1930). Studium. Revista de humanidades, 23, pp. 195-226.

Pomerantsev, P. (2017). La Nueva Rusia, nada es verdad. Barcelona: RBA.

Rangsimaporn, P. (2009). Russia as an aspiring great power in East Asia: perceptions and policies from Yeltsin to Putin. Basingstoke y Hampshire: Palgrave Macmillan.

Rosenstone, R. A. (2014). La historia en el cine. Madrid: Rialp.

Service, R. (2000). Historia de Rusia en el siglo XX. Barcelona: Crítica.

Service, R. (2005). Rusia, experimento de un pueblo: de 1991 a la actualidad. Madrid: Siglo XXI. 
Shevtsova, L. F. (2007). Russia lost in transition: the Yeltsin and Putin legacies. Washington: Carnegie Endowment for International Peace.

Taibo, C. (2000). La explosión soviética. Madrid: Espasa.

Taibo, C. (2017). La Rusia contemporánea y el mundo. Madrid: Catarata. 